Report file no.

22278

GRØNLANDS GEOLOGISKE UNDERSØGELSE Bulletin No. 126

Guprostibite and associated minerals from the Ilímaussaq intrusion, South Greenland

\author{
by \\ Sven Karup-Møller, Laust Løkkegaard, \\ Evgenu Ivanovich Semenov and Henning Sørensen
}




\section{Grønlands Geologiske Undersøgelse \\ (The Geological Survey of Greenland) \\ Øster Voldgade 10, DK-1350 Copenhagen K}

\section{Bulletins}

No. 113 Holocene history of the Greenland ice sheet based on radiocarbon-dated moraines in West Greenland. 1975 by N. W. Ten Brink. (Meddr Gronland 201,4).

D.kr. 40.00

No. 114 Ferri-sepiolite in hydrothermal calcite-quartz-chalcedony veins on Nûgssuaq in West Greenland. 1974 by K. Binzer \& S. Karup-Møller. (Meddr Grønland 201,5), $\quad$ D.kr. 12.50

No. 115 The Hurry Inlet granite and related rocks of Liverpool Land, East Greenland. 1975 by K. Coe.

D.kr. 26.00

No. 116 The crystal habit of naujakasite. 1975 by Ole V. Petersen and Steen Andersen. The crystal structure of naujakasite. 1975 by Riccardo Basso, Alberto Dal Negro, Antonio Della Giusta \& Luciano Ungaretti.

D.kr. 20.00

No. 117 Organic compounds from the Rhaetic-Liassic coals of Scoresby Sund, East Greenland. 1975 $\begin{array}{ll}\text { by K. R. Pedersen \& J. Lam. D.kr. } 16.00 & \end{array}$

No. 118 The South Qôroq Centre nepheline syenites, South Greenland. Petrology, felsic mineralogy $\begin{array}{ll}\text { and petrogenesis. } 1976 \text { by D. Stephenson. } & \text { D.kr. } 38.00\end{array}$

No. 119 Carbonates et stromatolites du sommet du Groupe d'Eleonore Bay (Précambrien terminal) au Canning Land (Groenland oriental). 1976 par J. Bertrand-Sarfati \& R. Caby. D.kr. 45.00

No. 120 Early Tertiary flood basalts from Hareøen and western Nûgssuaq, West Greenland. 1976 by N. Hald.

D.kr. 30.00

No. 121 Early Silurian (Late Llandovery) rugose corals from western North Greenland. 1977 by R. A. McLean.

D.kr. 46.00

No. 122 Gardiner intrusion, an ultramafic complex at Kangerdlugssuaq, East Greenland. 1977 by W. Frisch \& H. Keusen.

D.kr. 80.00

No. 123 Stratigraphy, tectonics and palaeogeography of the Jurassic sediments of the areas north of Kong Oscars Fjord, East Greenland. 1977 by F. Surlyk.

D.kr. 50.00

No. 124 The Fiskenæsset complex, West Greenland Part III Chemistry of silicate and oxide minerals from oxide-bearing rocks, mostly from Qeqertarssuatsiaq. 1977 by I. M. Steele, F. C. Bishop, J. V. Smith \& B. F. Windley.

D.kr. 27.00

No. 125 Petrology of the late lavas of the Eriksfjord Formation, Gardar province, South Greenland. 1977 by J. Gutzon Larsen.

D.kr. 25.00

No. 126 Cuprostibite and associated minerals from the Ilimaussaq intrusion, South Greenland. 1978 by S. Karup-Møller, L. Løkkegaard, E. I. Semenov \& H. Sørensen.

Bulletins up to no. 114 were also issued as parts of Meddelelser om Gronland, and are available from Nyt Nordisk Forlag - Arnold Busck, Købmagergade 49, DK-1150 Copenhagen K, Denmark. 


\title{
GRØNLANDS GEOLOGISKE UNDERSØGELSE
}

Bulletin No. 126

Cuprostibite and associated minerals

from the Ilímaussaq intrusion,

South Greenland

\author{
by \\ Sven Karup-Møller, Laust Løkkegaard, \\ Evgenu Ivanovich Semenov and Henning Sørensen
}

Contributions to the mineralogy of Ilimaussaq nos. 46 and 47 


\begin{abstract}
The mineral cuprostibite $\left(\mathrm{Cu}_{2} \mathrm{Sb}\right)$ is found in pneumatolytic-hydrothermal veins associated with lujavrite at three localities.

Cuprostibite occurs associated with loellingite, chalcopyrite, argentite, native silver and ?antimonian silver in analcime-ussingite-rich veins at the Taseq slope locality, with loellingite, chalcocite, dyscrasite, allargentum, galena and sphalerite in analcime-rich veins at the Kangerdluarssuk locality and with loellingite, rohaite, sphalerite, silver (1), silver (2), allargentum, digenite, chalcocite and cuprite in analcime-rich veins at the Kvanefjeld locality. Supergene alteration of cuprostibite and some of the associated ore minerals has taken place.

Cuprostibite occurs in granular masses. It has uneven fracture, a poor basal cleavage, purple colour, distinct metallic lustre, distinct reflectance pleochroism and strong, yellow, deep red to black-polarization colours. The microindentation hardness is $216-249\left(\mathrm{VHN}_{50 \mathrm{~g}}\right)$. Determined and calculated density 8.36 and $8.42 \mathrm{~g} / \mathrm{cm}^{3}$, respectively. Cuprostibite is tetragonal, $a 4.0000 \pm 0.0006 \AA$ and $c 6.1000 \pm 0.0017 \AA$. Microprobe analyses of two samples gave the formulae $\mathrm{Cu}_{2.02} \mathrm{Sb}_{0.98}$ and $\mathrm{Cu}_{2.10}\left(\mathrm{Sb}_{0.86} \mathrm{Tl}_{0.04}\right)_{0.9}$.

Dyscrasite, allargentum, galena, sphalerite and an unnamed mineral

$\left[(\mathrm{Sb}, \mathrm{Cu})_{2}(\mathrm{~Pb},[\mathrm{Fe}, \mathrm{Ca}]) \mathrm{Si}_{0.4}\left(0,0 \mathrm{H}, \mathrm{H}_{2} \mathrm{O}\right)_{\mathbf{y}}, \mathrm{y}=\max , 9.6\right]$ occur in very small amounts in association with cuprostibite at Kangerdluarssuk. Alteration of dyscrasite, allargentum and associated cuprostibite has resulted in the formation of antimonian silver as host for senarmontite, cuprite and native copper.

Rohaite $\left(\mathrm{TlCu}_{5} \mathrm{SbS}_{2}\right)$ from Kvanefjeld is a new mineral and is associated with chalcocite, cuprostibite, antimonian silver, cuprite, loellingite, and sphalerite. The mineral is tetragonal with $a 3.801 \pm 0.002 \AA$ and $c 20.986 \pm 0.008 \AA$. A superstructure has caused a doubling of the $a$ cell dimension. Rohaite has been partly altered to an extremely fine-grained mixture of digenite and senarmontite having the bulk chemical composition: $\mathrm{Sb}_{2} \mathrm{O}_{3} \cdot 3.86 \mathrm{Cu}_{1.93} \mathrm{~S}_{1.00}$ with small contents of thallium, iron and lead.

Supergene alteration of digenite and chalcocite at Kvanefjeld has resulted in the formation of two varieties of blaubleibender covellite $\left(\mathrm{Cu}_{1.13} \mathrm{~S}\right.$ and $\left.\mathrm{Cu}_{1.42} \mathrm{~S}\right)$, covellite and connellite. Djurleite $\left(\mathrm{Cu}_{1.96} \mathrm{~S}\right)$ has exsolved from the digenite.

Supergene alteration of cuprostibite has resulted in the formation of senarmontite, Sb-malachite, cuprites and native copper. Senarmontite occurs as very fine-grained material intergrown with an unidentified copper-antimony mineral. Sb-malachite may possibly be a submicroscopic mixture of normal malachite and an unidentified Sb-rich phase. 'Cuprites' comprise normal cuprite and closely associated phases containing variable amounts of antimony, lead and silicon.

Connellite, brochantite, linarite and senarmontite are supergene. Cell dimensions and microprobe analyses for connellite and linarite are listed.
\end{abstract}

\section{Authors' addresses:}

S.K-M.

Mineralogical Institute

Technical University of Denmark

DK-2800 Lyngby

Denmark
E.I.S.

\section{IMGRE}

Sadovnichevskaja 71

Moscow 113127

USSR
H.S. \& L.L.*

Institute of Petrology

University of Copenhagen

Øster Voldgade 5

DK-1350 Copenhagen $\mathrm{K}$

"Laust Løkkegaard died in 1972. 


\section{CONTENTS}

INTRODUCTION

H. Sørensen

THE OCCURRENCE OF CUPROSTIBITE

................... S. Karup-Møller, L. Løkkegaard, E. I. Semenov, H. Sørensen

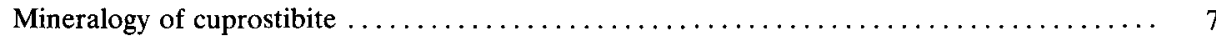

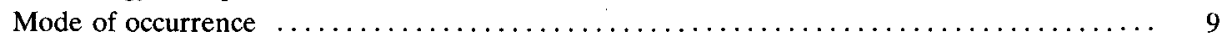

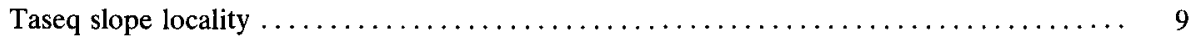

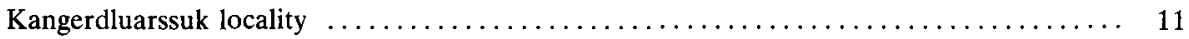

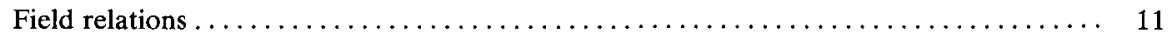

Petrology of the cuprostibite-bearing analcime-aegirine veins $\ldots \ldots \ldots \ldots \ldots \ldots \ldots, 13$

Mineralogy and paragenetical relations of cuprostibite and associated ore minerals .... 14

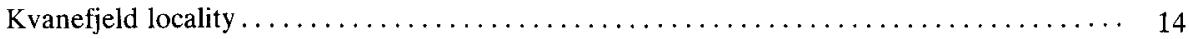

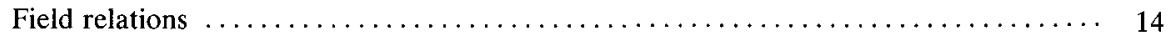

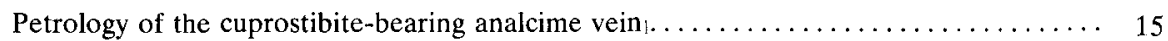

Mineralogy and paragenetical relations of cuprostibite and associated ore minerals .... 16

Discussion .................................................. 19

PRIMARY AND SECONDARY ORE MINERALS ASSOCIATED WITH CUPROSTIBITE

S. Karup-Møller 23

Dyscrasite, allargentum and associated minerals at the Kangerdluarssuk cuprostibite locality 23

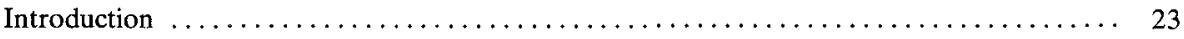

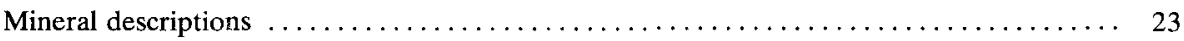

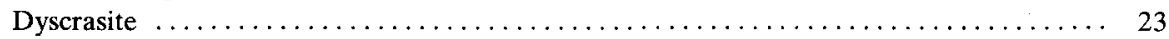

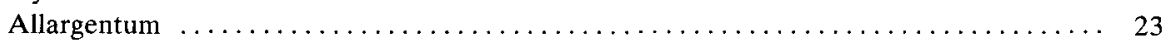

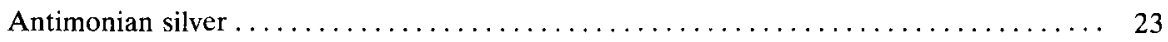

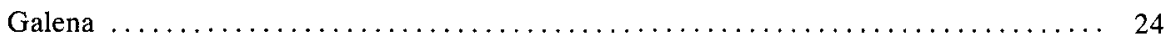

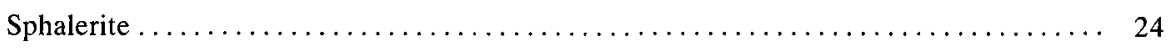

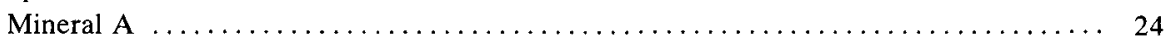

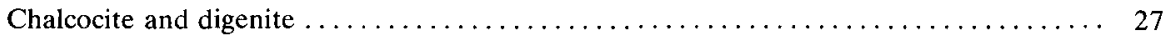

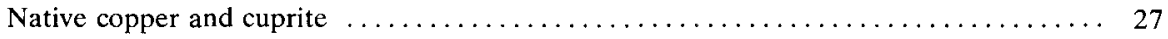

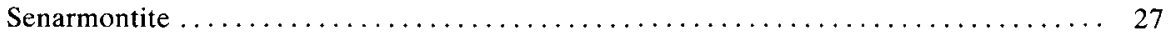

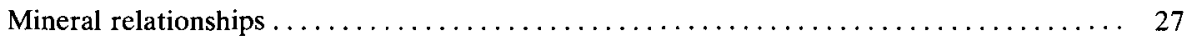

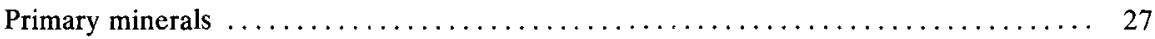

Mode of occurrence of dyscrasite $\ldots \ldots \ldots \ldots \ldots \ldots \ldots \ldots \ldots \ldots \ldots \ldots \ldots \ldots \ldots \ldots, 27$

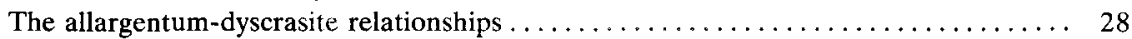

The mineral A - dyscrasite relationships $\ldots \ldots \ldots \ldots \ldots \ldots \ldots \ldots \ldots \ldots \ldots \ldots \ldots \ldots \ldots \ldots, 28$

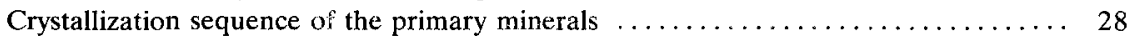

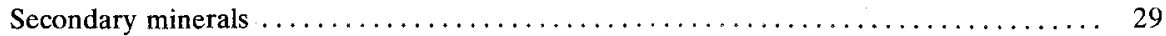

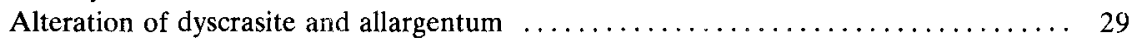

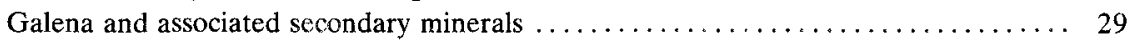

Mode of formation of digenite and chalcocite $\ldots \ldots \ldots \ldots \ldots \ldots \ldots \ldots \ldots \ldots, 30$

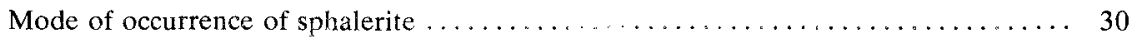


Formation of primary and secondary ore minerals $\ldots \ldots \ldots \ldots \ldots \ldots \ldots \ldots \ldots \ldots \ldots$

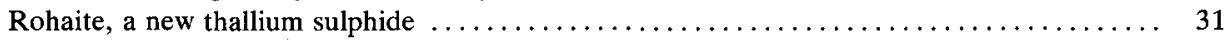

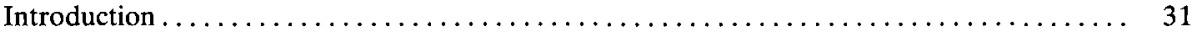

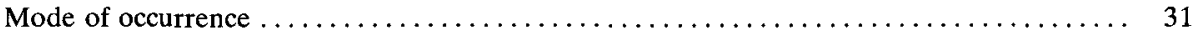

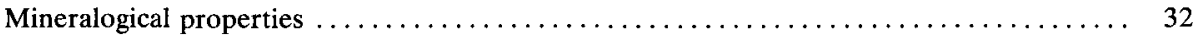

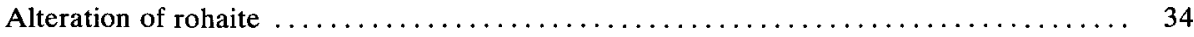

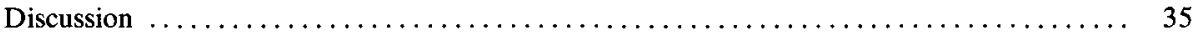

Chalcocite, digenite and associated secondary minerals from the Kvanefjeld cuprostibite locality 36

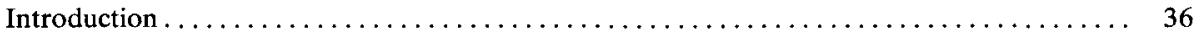

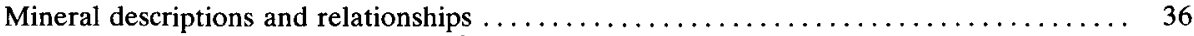

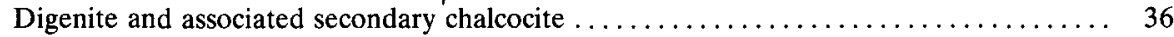

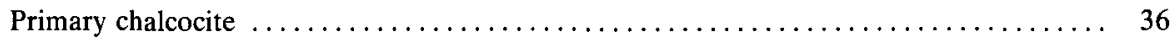

Blaubleibender covellite $\ldots \ldots \ldots \ldots \ldots \ldots \ldots \ldots \ldots \ldots \ldots \ldots \ldots \ldots \ldots \ldots \ldots \ldots \ldots, 36$

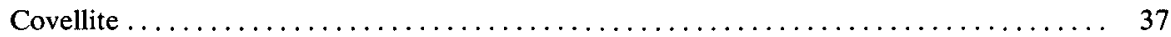

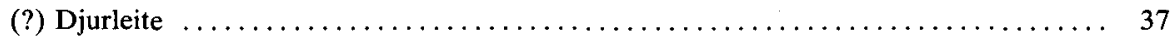

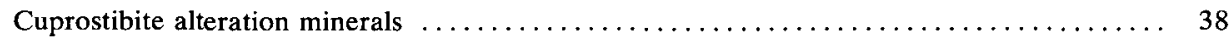

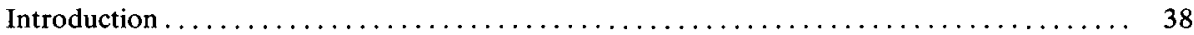

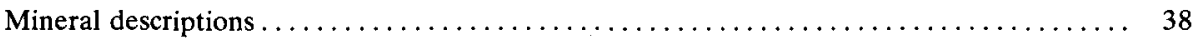

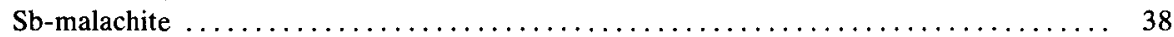

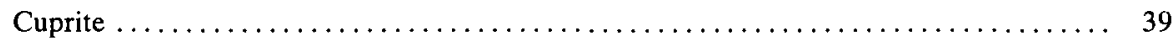

Senarmontite and the associated unidentified mineral $\ldots \ldots \ldots \ldots \ldots \ldots \ldots \ldots \ldots \ldots \ldots$

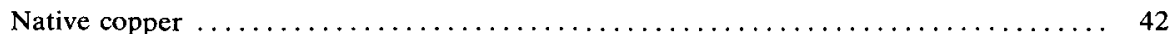

Mineral relationships $\ldots \ldots \ldots \ldots \ldots \ldots \ldots \ldots \ldots \ldots \ldots \ldots \ldots \ldots \ldots \ldots \ldots \ldots \ldots \ldots \ldots \ldots$

Conditions of formation $\ldots \ldots \ldots \ldots \ldots \ldots \ldots \ldots \ldots \ldots \ldots \ldots \ldots \ldots \ldots \ldots \ldots \ldots \ldots \ldots, \ldots \ldots \ldots$

The occurrence of connellite, brochanitite, linarite and senarmontite $\ldots \ldots \ldots \ldots \ldots \ldots$

Introduction $\ldots \ldots \ldots \ldots \ldots \ldots \ldots \ldots \ldots \ldots \ldots \ldots \ldots \ldots \ldots \ldots \ldots \ldots \ldots \ldots \ldots \ldots$

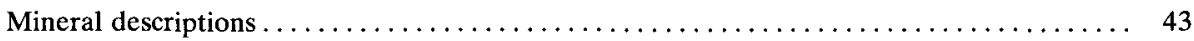

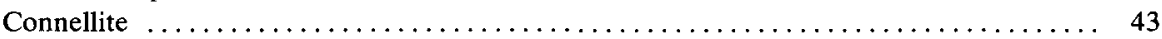

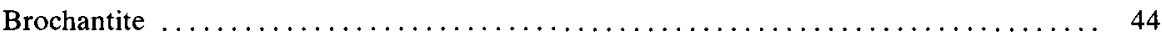

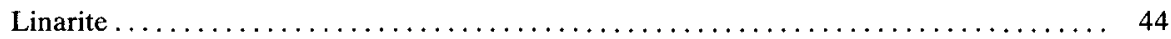

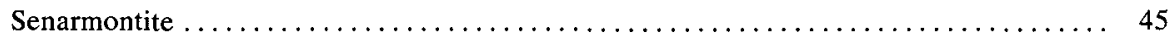

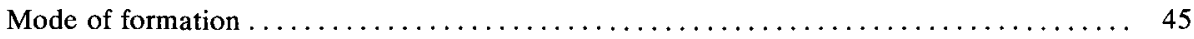

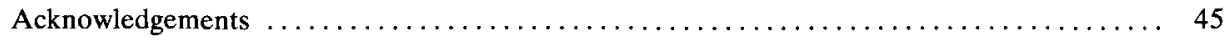

REFERENCES $\ldots \ldots \ldots \ldots \ldots \ldots \ldots \ldots \ldots \ldots \ldots \ldots \ldots \ldots \ldots \ldots \ldots \ldots \ldots \ldots \ldots$ 


\section{INTRODUCTION}

The minerals chalcothallite and cuprostibite were described as new minerals by Semenov et al. (1967) and Sørensen et al. (1969) respectively. These minerals were discovered in 1964 in ussingite veins on the Taseq slope in the northern part of the Ilímaussaq intrusion in South Greenland (fig. 1). In 1968 cuprostibite was also found in an analcime vein on the Kvanefjeld plateau to the north of the Taseq slope, and in 1970 relatively large quantities of this mineral were found in analcime-aegirine veins at the head of the Kangerdluarssuk fjord in the southern part of the intrusion. The minerals identified so far at these three localities are listed in Table 1.

The type material on which the first description of cuprostibite (Sørensen et al., 1969) is based, is kept at IMGRE, Sadovnichevskaja 71, Moscow 113127, USSR; the material described in the present paper is kept in the Geological Museum of the University of Copenhagen.

Several primary and secondary ore minerals occur associated with cuprostibite. Those at the type locality for cuprostibite on the Taseq slope have been mentioned by Sørensen et al. (1969), those at the other two localities of Kvanefjeld and Kangerdluarssuk are described here.

Unless otherwise stated, all microprobe analyses have been carried out with a Hitachi model XMB-5S microprobe at $20 \mathrm{kV}$.

Henning Sørensen. 


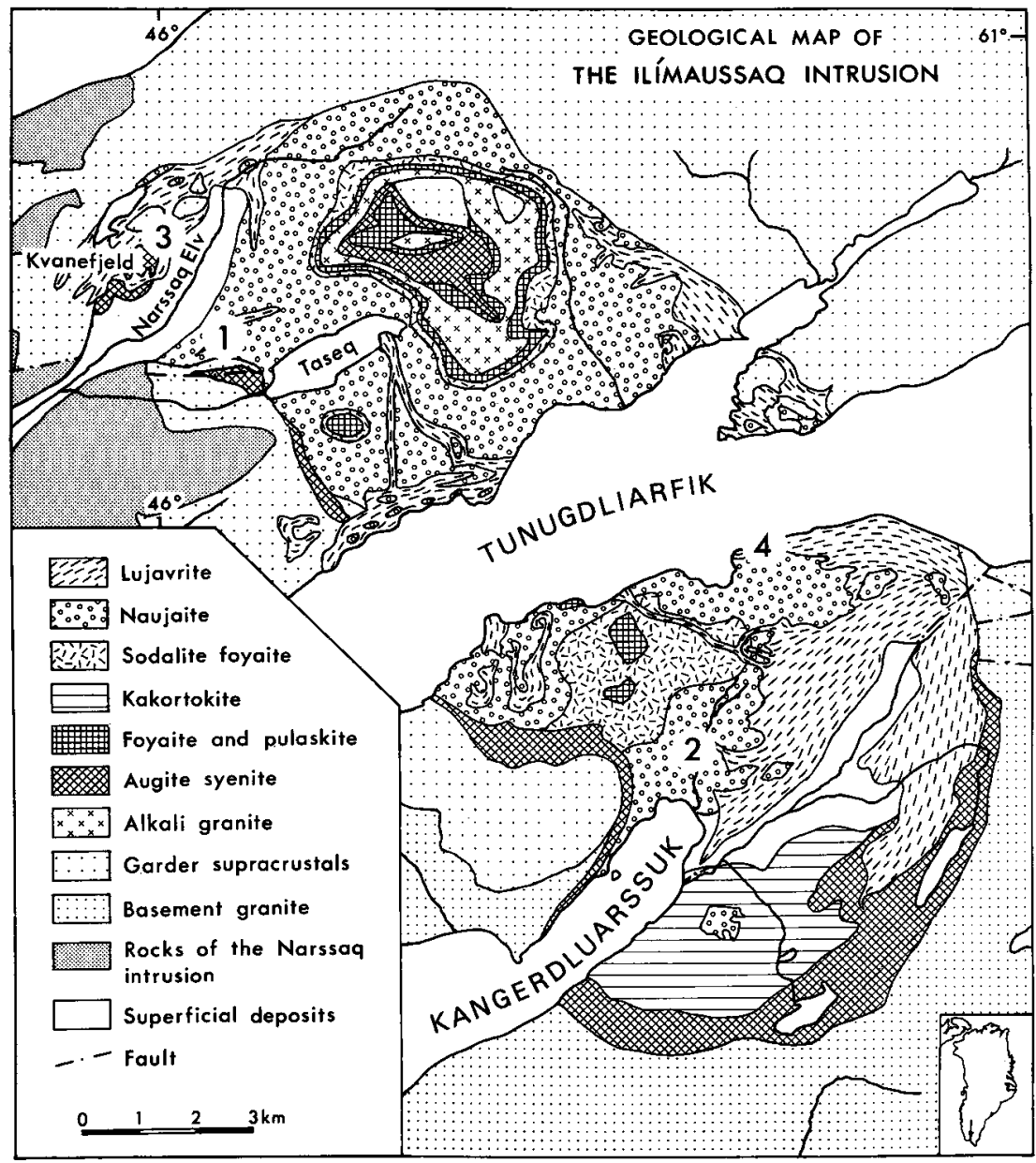

Fig. 1. Geological map of the Ilimaussaq intrusion (modified after Ferguson, 1964), showing locations of copper-antimony mineral occurrences. 1: Taseq slope, 2: Kangerdluarssuk plateau, 3: Kvanefjeld plateau, 4: Tuperssuatsiait. 


\title{
THE OCCURRENCE OF CUPROSTIBITE*
}

\author{
Sven Karup-Møller, Laust Løkkegaard, \\ Evgenu Ivanovich Semenov and Henning Sørensen
}

\section{Mineralogy of cuprostibite}

The mineralogical data on cuprostibite from the Taseq type locality have been presented by Sørensen et al. (1969), those on the mineral from the Kangerdluarssuk locality by López-Soler et al. (1975).

Cuprostibite forms granular aggregates with an average grain size of $0.5 \mathrm{~mm}$. The mineral is purple to pink in hand specimen resembling tarnished bornite. The mineral has a distinct metallic lustre. The fracture is uneven, a basal cleavage is poorly developed. Some grains display polysynthetic twinning after two directions perpendicular to each other. Rough polishing with coarse carborundum often results in the formation of deformation twins.

The microindentation hardness determined on cuprostibite from the Taseq type locality is $220\left(\mathrm{VHN}_{50 \mathrm{~g}}\right)$. Values obtained on the mineral from the Kangerdluarssuk locality range from 216 to 249 , the average being $233\left(\mathrm{VHN}_{50}\right.$ g, 16 determinations).

Etching of cuprostibite from the Kangerdluarssuk locality for one minute gave negative results with the following reagents: $\mathrm{FeCl}_{3}(20 \%), \mathrm{HgCl}_{2}(5 \%), \mathrm{KCN}$ $(20 \%)$ and $\mathrm{KOH}(40 \%)$. With $\mathrm{HNO}_{3}(1: 1)$ the polished surface is destroyed and turns pitch black. With $\mathrm{HCl} \mathrm{(1:1)} \mathrm{a} \mathrm{similar} \mathrm{but} \mathrm{less} \mathrm{intensive} \mathrm{effect} \mathrm{is} \mathrm{achieved.}$

The reflectance colour of cuprostibite is purple and the reflectivity is rather high. Reflectance pleochroism is distinct both in air and in oil immersion. The reflectance data for the mineral were determined by López-Soler et al. (1975). Reflectance values were measured in air and oil at wave lengths between 400 and $1100 \mathrm{~nm}$ and in air and glycerine between 250 and $400 \mathrm{~nm}$. Cuprostibite is optically negative between 250 and $620 \mathrm{~nm}$ and optically positive between 620 and $1100 \mathrm{~nm}$. The reflectance values, refractive indices and absorption coefficients at the four principal wave lengths are listed in Table 2.

Cuprostibite is strongly anisotropic under crossed nicols both in air and in oil immersion. The anisotropy colours are vivid and mainly yellow, deep red and black.

Cuprostibite is tetragonal, $a 4.000 \pm 0.0006 \AA$ and $c 6.1000 \pm 0.0017 \AA$ (based on Guinier film no. 1611 of material from the Kangerdluarssuk locality). Reflections of all orders are present. The guinier powder data have been published by López-Soler $e t$ al. (1975).

The crystallographic properties of cuprostibite closely resemble those of rickardite $\left(\mathrm{Cu}_{3} \mathrm{Te}_{2}\right)$. The data on rickardite given by Strunz (1970) are: $a 3.98, c 6.12$ and space group $\mathrm{P} 4 / \mathrm{nmm}$.

* Contribution to the mineralogy of Ilímaussaq no. 46. 


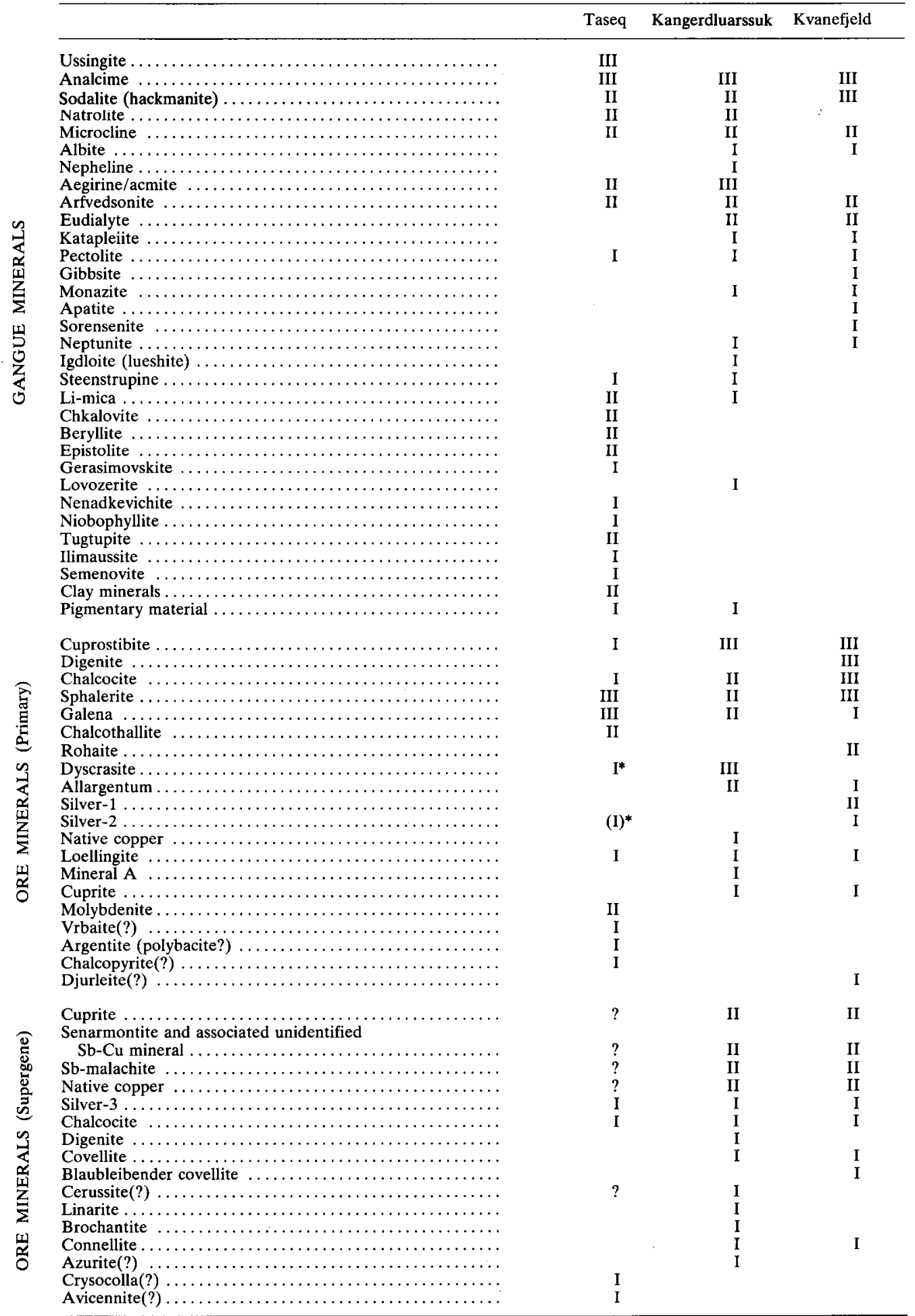

* Composition not determined.

Relative frequency amongst the ore minerals and the gangue minerals is indicated: III common, II minor and I trace. Minerals from the Taseq locality based partly on Engell et al., 1971, table 3. 
Table 2. Optical properties of cuprostibite

\begin{tabular}{|c|c|c|c|c|}
\hline$\lambda_{\mathrm{nm}}$ & 481 & 546 & 589 & 644 \\
\hline$R_{\mathrm{o}}$ (air) $\ldots \ldots \ldots \ldots \ldots \ldots$ & 47.3 & 36.8 & 37.1 & 51.8 \\
\hline$R_{\mathrm{e}}($ air $) \ldots \ldots \ldots \ldots \ldots \ldots \ldots$ & 52.5 & 44.2 & 42.2 & 49.8 \\
\hline$\ldots \ldots \ldots \ldots \ldots \ldots$ & 33.1 & 25.7 & 27.3 & 39.9 \\
\hline$R_{\mathrm{e}}$ (oil) & 37.8 & 29.4 & 28.6 & 36.8 \\
\hline$n_{\mathrm{o}} \ldots \ldots \ldots \ldots \ldots \ldots \ldots \ldots \ldots \ldots \ldots$ & 2.82 & 1.68 & 1.37 & 1.76 \\
\hline$n_{\mathrm{e}} \ldots \ldots \ldots \ldots \ldots \ldots \ldots \ldots \ldots \ldots \ldots$ & 4.14 & 3.43 & 2.49 & 2.27 \\
\hline$k_{\mathrm{o}} \ldots \ldots \ldots \ldots \ldots \ldots \ldots \ldots \ldots$ & 2.61 & 1.86 & 1.77 & 2.64 \\
\hline$k_{\mathrm{e}} \ldots \ldots \ldots \ldots \ldots \ldots \ldots \ldots \ldots \ldots \ldots \ldots$ & 2.92 & 2.24 & 2.26 & 2.72 \\
\hline
\end{tabular}

Reflectance values $(R)$, refractive indices $(n)$ and absorption coefficients $(k)$. Kangerdluarssuk locality.

Microprobe analyses on nine grains from the Kangerdluarssuk locality gave: $\mathrm{Cu}$ $51.8-52.1$ (average 52.0\%) and $\mathrm{Sb} 46.2-50.5$ (average $48.8 \%$ ) suggesting the formula $\mathrm{Cu}_{2.02} \mathrm{Sb}_{0.98}$ which is near the ideal formula $\mathrm{Cu}_{2} \mathrm{Sb}$. No other elements were detected by the microprobe. At the Taseq locality the average of three analyses gave: $\mathrm{Cu} 53.3 \%$, Sb $42.0 \%$, Tl 3.5\%, Ag 0.1\% and S 1.1\% (Sørensen et al., 1969) with a suggested formula $\mathrm{Cu}_{2.10}\left(\mathrm{Sb}_{0.86} \mathrm{Tl}_{0.04}\right)_{0.9}$ where thallium is considered to have substituted for antimony and the silver, sulphur and bismuth values may represent submicroscopic minerals enclosed in the cuprostibite. (The composition $\mathrm{Cu}_{3} \mathrm{Sb}$ given by Hey, 1970, page 956 and the composition $\mathrm{Cu}(\mathrm{Sb}, \mathrm{Te})$ by Ramdohr, 1975, for cuprostibite from Taseq are erroneously referenced). At the Kvanefjeld locality the mineral does not contain detectable amounts of thallium even though rohaite may occur enclosed in the cuprostibite. Qualitative spectrographic analyses of material from the Taseq locality indicated the presence of trace amounts of $\mathrm{Bi}$ and $\mathrm{Fe}$; inclusions of loellingite determined optically explain the presence of iron.

The specific gravity of cuprostibite from the Taseq type locality could not be determined due to insufficient amounts of material. A specific gravity of 8.36 $\mathrm{g} / \mathrm{cm}^{3}$ was determined on the mineral from the Kangerdluarssuk locality. The calculated specific gravity for ideal cuprostibite $\left(\mathrm{Cu}_{2} \mathrm{Sb}\right)$ is $8.42 \mathrm{~g} / \mathrm{cm}^{3}$. This corresponds to a unit cell content of two formula units.

\section{Mode of occurrence}

\section{Taseq slope locality}

The chalcothallite-cuprostibite-bearing ussingite vein is located at an altitude of $535 \mathrm{~m}$ in the north-west part of the Taseq slope. This locality has been mapped and described by Engell et al. (1971, fig. 3). 
The ussingite vein intersects naujaite and is closely associated with lujavrite veins and aegirinitized naujaite. The ussingite encloses felted aegirine, sodalite, chkalovite and minor sphalerite, galena and molybdenite. Chalcothallite, cuprostibite etc. are of rather restricted occurrence. The ussingite vein is rich in rare minerals (Table 1).

The chalcothallite and cuprostibite form small independent pockets and spots in the ussingite and are generally covered by a crust of green, orange and red alteration products. The two primary minerals have not been observed with each other.

The cuprostibite aggregates are up to $1.5 \mathrm{~mm}$ across and, according to Sørensen et al. (1969), contain rare inclusions of loellingite, chalcopyrite, argentite, native silver and (?)antimonian silver. The loellingite occurs as isolated euhedral inclusions in cuprostibite and as grain aggregates. It is more resistant to weathering than cuprostibite and is therefore present in the crusts of the secondary minerals. Antimonian silver is enclosed in cuprostibite and is often in direct contact with loellingite.
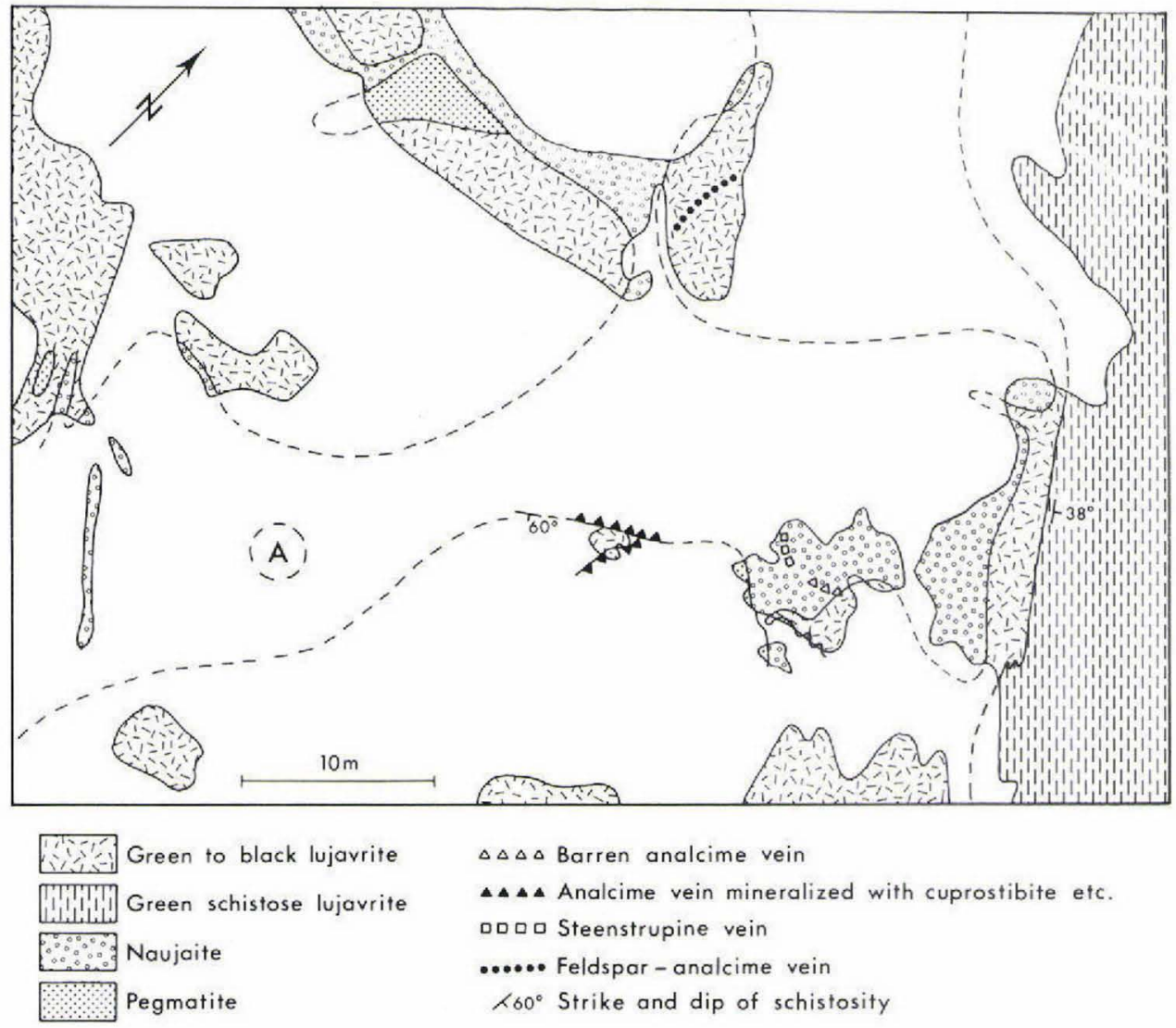

$\Delta \Delta \Delta \Delta$ Barren analcime vein

A. Analcime vein mineralized with cuprostibite efc. 口वप् Steenstrupine vein

-... Feldspar-analcime vein

$\angle 60^{\circ}$ Strike and dip of schistosity

(A), Area in till with boulders containing $\mathrm{Cu}-\mathrm{Sb}$ sulphides and oxides

Fig. 2. Geological plan of locality 2 at Kangerdluarssuk in fig. 1. 


\section{Kangerdluarssuk locality}

\section{Field relations}

This occurrence was discovered by Henning Bohse and the late Laust Løkkegaard in the summer of 1970 in a block of rock measuring $2 \times 2 \times 0.7 \mathrm{~m}$ (fig. 3 ). The block was found on the plateau about $1 \mathrm{~km}$ to the north-east of the head of Kangerdluarssuk at an altitude of approximately $300 \mathrm{~m}$ (fig. 1).

As shown in fig. 2 the cuprostibite-bearing analcime-aegirine veins are located in a contact zone between naujaite and lujavrite, and between lujavrite and lujavrite pegmatite.

The block was broken by dynamite blasting parallel to the line A-A' shown in figs 3 and 4 ; the resulting cross-section is shown in fig. 5.

The north side of the block (fig. 3) showed remnants of a $10-20 \mathrm{~cm}$ thick analcime vein locally containing as much as 15 per cent cuprostibite and associated ore minerals (GGU 151530, 151531 and 151532). After removal of the till around the block the vein was found in the bedrock just below the block along the contact between naujaite and lujavrite. The block has thus been detached from the immediately underlying bedrock. The contact of the vein against the naujaite was knife sharp, but the vein passed gradually into the lujavrite (GGU 151532). Thin section studies have revealed that not only naujaite, but also lujavrite and lujavrite pegmatite are altered near the veins.

The northern top portion of the block was covered by a $3-10 \mathrm{~cm}$ thick aegirine-felt vein (fig. 4) in lujavrite. This vein joined the mineralized analcime-aegirine vein mentioned above, apparently forming a subsidiary branch of the vein. It contained

Fig. 3. Block with cuprostibite at the Kangerdluarssuk locality (fig. 1). The analcime vein with cuprostibite etc. follows the side of the block facing the photographer. A cross-section in the block parallel to the line $\mathrm{A}-\mathrm{A}^{\prime}$ is shown in fig. 4 .

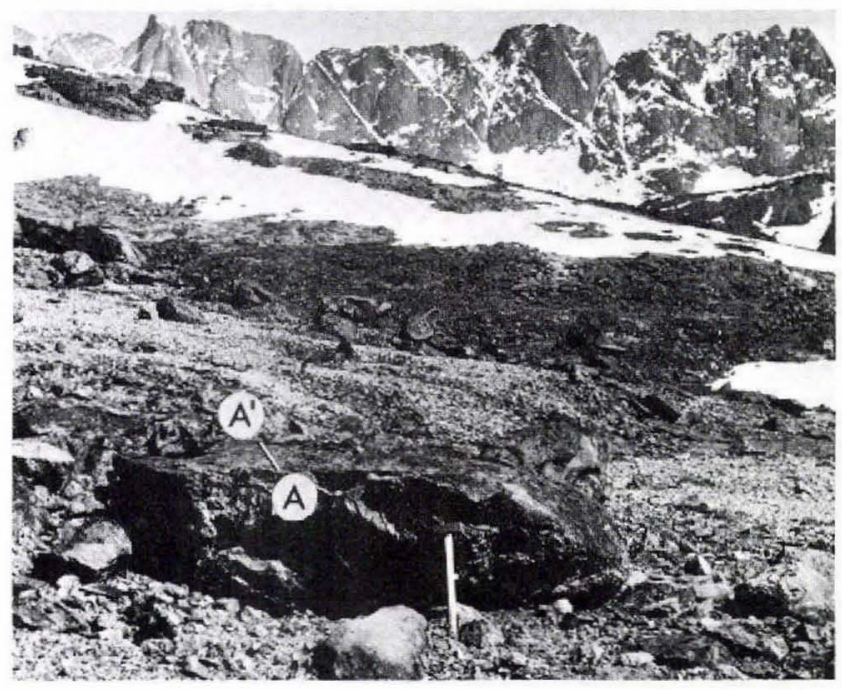



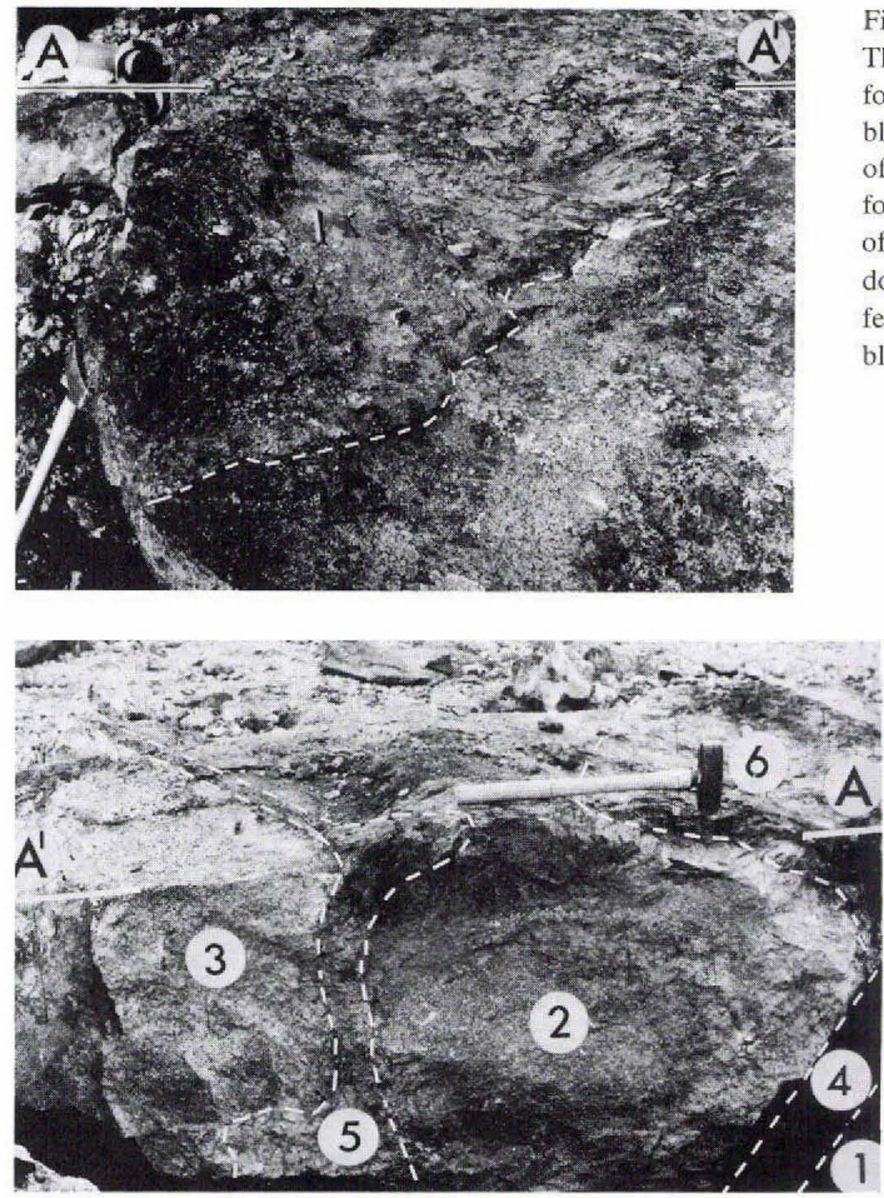

Fig. 5. Section through the block after it was blasted with dynamite. 1: position of naujaite, and 4: position of the mineralized analcime vein before the blasting. 2 : greenish-black lujavrite. 3 : lujavrite pegmatite. 5: sparsely mineralized analcime vein with narrow stringers of aegirine towards the right in the vein. 6: aegirine felt vein, seen also in fig. 4 .

isolated cuprostibite aggregates up to one centimetre across. The average content of this mineral hardly exceeded one per cent of the vein.

The south-eastern corner of the block consisted of lujavrite pegmatite which was separated from the lujavrite by a $10-20 \mathrm{~cm}$ thick vein of aegirine-analcime material (fig. 5). Only very few cuprostibite aggregates, generally less than three millimetres across, were found in this vein, in particular within its coarse-grained aegirine-poor bottom portion. In addition, 2-3 $\mathrm{mm}$ large aggregates of galena showing partial alteration into cerussite (or hydrocerussite), digenite and chalcocite were rarely present, sometimes partly surrounding cuprostibite aggregates. Such galena aggregates have not been observed in the vein on the north side of the block.

A few erratic analcime boulders, presumably derived from nearby unexposed mineral veins, contain small ore mineral aggregates composed of skinnerite, tetrahedrite, chalcostibite, native antimony, valentinite, senarmonite, and traces of loel- 
lingite and galena (Karup-Møller, 1974). This is the only locality where the mineral skinnerite has been found (Karup-Møller \& Makovicky, 1974). The boulders were found in the area marked $\mathrm{A}$ in fig. 2, approximately $15 \mathrm{~m}$ to the south-west of the cuprostibite occurrence.

\section{Petrology of the cuprostibite-bearing analcime-aegirine veins}

The vein of felt-like aegirine is made up by dense aggregates of needles of aegirine (GGU 151324). There are scattered prisms of aegirine up to $1 \mathrm{~cm}$ long. Arfvedsonite is occasionally present. Generally there is a matrix composed of analcime and natrolite. Tabular crystals of microcline and areas of pigmentary material, which are often associated with grains of neptunite, are generally present. There are crystals of steenstrupine, lovozerite, Li-mica, pectolite, igdloite, monazite and eudialyte or altered eudialyte. The cuprostibite occurs as irregular masses, generally up to one centimetre across. It occurs interstitially to aegirine prisms and along fractures and cleavages in this mineral. The cuprostibite also contains numerous randomly distributed tiny aegirine crystals. The cuprostibite thus formed penecontemporaneously with or later than aegirine. Cuprostibite also forms veins in the analcime matrix.

The analcime vein material (GGU 151321) is composed of large anhedra of analcime, prismatic crystals of aegirine up to $2 \mathrm{~cm}$ long, grains of yellowish sodalite up to a few centimetres across, and occasional small plates of microcline. Under the microscope corroded grains of nepheline and aggregates of fine-grained natrolite have been observed. The large prisms of aegirine are broken and impregnated with pigmentary material along the fractures. The aegirine crystals may be replaced by felt-like aegirine and neptunite. The pigmentary material contains grains of neptunite, altered lovozerite, steenstrupine, fine-grained aggregates of monazite, aegirine needles, pectolite and perhaps $\mathrm{Li}$-mica. The analcime encloses scattered grains of igdloite (lueshite), monazite, steenstrupine, (?)lovozerite and large prismatic grains of pectolite. Small grains of eudialyte may be present. They are generally replaced by katapleiite and other secondary minerals. Cuprostibite occurs as large aggregates in the analcime and as smaller grains in the pigmentary material in aegirine. The larger cuprostibite aggregates have off-shoots into fractures in the enclosing analcime. Some cuprostibite aggregates contain inclusions of aegirine needles.

Minor amounts of cuprostibite occur in the naujaite adjacent to the veins up to a distance of $10 \mathrm{~cm}$ from these. There are also dots of cuprostibite in the lujavrite.

The naujaite adjacent to the veins (GGU 151534) is rich in analcime which replaces microcline, nepheline and sodalite. There are scattered crystals of steenstrupine, minor amounts of cuprostibite and associated ore minerals, aggregates of pectolite, and grains of eudialyte partly replaced by katapleiite. 
Mineralogy and paragenetical relations of cuprostibite and associated ore minerals

The cuprostibite aggregates enclose a few crystals of loellingite and dyscrasite. Cuprostibite often contains abundant very fine-grained aegirine needles. Galena was originally present in the aggregates but is now completely replaced by chalcocite. However, the major part of the associated primary ore minerals are enclosed in the silicate minerals adjacent to cuprostibite and appear to have formed at a late stage in the crystallization sequence. These ore minerals are dyscrasite, allargentum, galena, sphalerite, cuprite, and mineral A. Alteration of the copper-antimony minerals has resulted in the formation of antimonian silver as host for senarmontite, cuprite and native copper or both. Galena is partly replaced by cerussite (hydrocerussite) and digenite. The latter mineral was later transformed into chalcocite. Mineral A $(\mathrm{Sb}, \mathrm{Cu})_{2}(\mathrm{~Pb}, \mathrm{Fe}, \mathrm{Ca}) \mathrm{Si}_{0.4}\left(\mathrm{O}, \mathrm{OH}, \mathrm{H}_{2} \mathrm{O}\right)_{y}$ is considered new. It may possibly belong to the stibiconite group of minerals.

The alteration of cuprostibite has resulted in the formation of Sb-malachite, senarmontite and an associated unidentified $\mathrm{Cu}-\mathrm{Sb}$ mineral, cuprite and native copper (see later).

Cavities with one or several of the minerals brochantite, connellite, senarmontite, linarite and malachite (or azurite) have been found in vein material poor in cuprostibite. The cavities are less than one centimetre in size. These minerals are considered to be of supergene origin (see later).

\section{Kvanefjeld locality}

\section{Field relations}

Cuprostibite, rohaite and various copper sulphides occur as disseminated grains in an analcime-rich zone along a trachyte dyke in the southern part of the Kvanefjeld plateau (fig. 1), about $25 \mathrm{~m}$ to the east of the entrance to the exploration drift shown on the geological map of the Kvanefjeld area (Sørensen et al., 1974).

Small amounts of chalcocite have been found in analcime veins in the area just to the north and west of the exploration drift. Cuprostibite has not been observed in these veins, which are rich in beryllium minerals such as sorensenite, chkalovite, and beryllite as well as sphalerite, pyrochlore, galena, molybdenite, steenstrupine etc.

The cuprostibite occurs in an analcime-sodalite zone along the contact of an up to $2 \mathrm{~m}$ wide dyke-like body of trachyte, which can be followed for more than $50 \mathrm{~m}$. The trachyte dyke traverses the medium to coarse-grained lujavrite with a sometimes wavy course. It wedges out in analcime-rich material in the lujavrite. Fragments of trachyte, in part folded, can be seen elsewhere on the plateau in the same body of medium to coarse-grained lujavrite.

The trachyte dyke is separated along both contacts from the lujavrite by zones of analcime-sodalite, varying in thickness from a few centimetres to about one metre. 
Locally the analcime-sodalite rock brecciates the trachyte. Similar zones of analcime-sodalite are found everywhere along the contacts between bodies of medium to coarse-grained lujavrite and remnants of the volcanic roof of the intrusion.

The field relations indicate that the trachyte was emplaced earlier than the medium to coarse-grained lujavrite but later than the fine-grained lujavrites. The trachyte may thus be considered as a screen of pre-existing rock which has survived the intrusion of the medium to coarse-grained lujavrite. A similar trachyte has been met in drill hole no. 37 at a depth of $340 \mathrm{~m}$ below the surface. The top of this drill hole is situated a few metres to the south of the cuprostibite locality.

Cuprostibite and the associated ore minerals have only been found in the analcime-sodalite rock along the northern contact of the trachyte.

\section{Petrology of the cuprostibite-bearing analcime vein}

The cuprostibite-bearing analcime vein consists of rounded grains of sodalite-analcime up to more than five centimetres across, with interstitial aggregates of felt-like arfvedsonite and a fine-grained matrix of analcime with small needles of arfvedsonite.

The analcime-sodalite grains often have pale green cores of sodalite and white marginal zones of analcime, the latter mineral being predominant. The sodalite has small microlites of arfvedsonite. The surrounding analcime contains in places small flakes of gibbsite which is an indication of the former presence of sodalite.

The interstitial patches of arfvedsonite consist of aggregates of needles of arfvedsonite and minor neptunite.

The matrix of finer-grained analcime contains small plates of microcline, scarce albite, needles of arfvedsonite, strongly altered eudialyte, pectolite, clusters of small crystals of monazite, apatite and irregular grains of sorensenite.

Some parts of the sodalite-analcime rock has a deformed look in hand specimen, elongated light-coloured masses being enclosed in a finer-grained matrix. In thin section the elongated masses are seen to consist of aggregates of small plates of microcline enclosed in a matrix of analcime which appears to corrode the microcline. The matrix also contains microcline laths, arfvedsonite, neptunite, apatite and monazite. The apatite contains inclusions of monazite. The microcline of this peculiar rock may have been derived from the trachyte.

The ore minerals are mainly found in masses of analcime along the contact of the trachyte. The trachyte holds minor cuprostibite etc. up to $10 \mathrm{~cm}$ from the contact.

The trachyte is altered along the contact with the vein; arfvedsonite replaces pyroxene and there is interstitial analcime with inclusions of microcline, partly in the form of fragments of 'microclinite'. There are clusters of monazite, and also sphalerite, acmitic pyroxene and neptunite. The ore minerals occur interstitial to the microcline, as inclusions in analcime, and partly as overgrowths on acmite.

The vein material (GGU 150102 and 151102) containing the copper minerals has 
fine plates of microcline and in some places albite in a matrix of analcime. The vein also contains pectolite, neptunite, monazite aggregates, minor arfvedsonite, acmite, apatite and steenstrupine. The ore minerals occupy interstices between and fractures in the microcline and form elongated aggregates. In places the ore minerals are associated with acmite, or with monazite, neptunite and pectolite.

\section{Mineralogy and paragenetical relations of cuprostibite and associated ore minerals}

Cuprostibite and associated ore minerals occur in very scarce amounts disseminated along the analcime vein. The ore minerals are mainly contained in aggregates dominated by one of the following three minerals: rohaite, digenite or cuprostibite. Rare aggregates of three antimonian silver varieties and allargentum are present.

Rohaite $\left(\mathrm{TlCu}_{5} \mathrm{SbS}_{2}\right)$ is a new mineral species (see later). It has been found as inclusions in cuprostibite and antimonian silver. The mineral may also form up to one centimetre large aggregates associated with chalcocite and sphalerite or both. These aggregates lie in silicates. Partial alteration of rohaite has resulted in the formation of a very fine-grained intergrowth of digenite and senarmontite.

High digenite, decomposed into a mixture of low digenite and chalcocite, crystallized in aggregates, half a centimetre in size, sometimes associated with sphalerite. The aggregates lie in the silicate minerals. A mineral, possibly djurleite, has exsolved from the high digenite. Supergene alteration has resulted in the formation of covellite, blaubleibender covellite and connellite.

Cuprostibite forms lensoid to veinlet shaped masses rarely exceeding one centimetre in size. Alteration of the mineral has resulted in the formation of the same secondary minerals as at the Kangerdluarssuk cuprostibite locality. Grains of antimonian silver, rohaite, chalcocite and galena have crystallized interstitial to the cuprostibite grains. Antimonian silver (described as silver (1) below) is generally present alone, while rohaite and chalcocite sometimes occur together. At places where the cuprostibite has been altered into senarmontite, veinlets of primary chalcocite occasionally mark the contacts between the original cuprostibite grains. Chalcocite rarely encloses idiomorphic cuprostibite crystals (Plate 1a). All galena has been completely replaced by chalcocite which is characterized by a similar delicate fracture pattern as the chalcocite secondary after galena at locality 2 in fig. 1 (Plates 2 and 3). Such chalcocite pseudomorphs after galena occur either isolated in the cuprostibite or intergrown with primary chalcocite and sometimes also with rohaite. Pseudomorphs of chalcocite after galena, which are intergrown with primary chalcocite, have also been observed isolated in silicates. Similar pseudomorphs form inclusions in cuprite.

Loellingite is enclosed in cuprostibite and is more common here than in the cuprostibite from the Kangerdluarssuk locality. The two loellingite crystals shown in Plate $1 \mathrm{~b}$ are separated from each other by silver(1) (Table 3 ) which presumably 
Table 3. Microprobe analyses of allargentum (A1) and the three antimonian silver varieties $S(1), S(2)$ and $S(3)$ from Kvanefjeld

\begin{tabular}{|c|c|c|c|c|c|}
\hline & Mineral analyzed & $\begin{array}{c}\text { Number } \\
\text { of ana- } \\
\text { lyses }\end{array}$ & $\begin{array}{c}\mathrm{Ag} \\
\text { Wt. \% }\end{array}$ & $\begin{array}{c}\mathrm{Sb} \\
\text { Wt. } \%\end{array}$ & Sum \\
\hline 1 & $\mathrm{~S}(1)$ shown in Plate $1 \mathrm{c} \ldots \ldots \ldots \ldots \ldots \ldots \ldots \ldots \ldots \ldots$ & 2 & 96.4 & 2.7 & 99.1 \\
\hline \multirow[t]{2}{*}{2} & $S(1)$ in graphic intergrowth with cuprite $\ldots \ldots \ldots \ldots$ & 4 & 94.0 & 4.4 & 98.4 \\
\hline & Aggregate 1 & & & & \\
\hline 3 & $S(1)-$ primary & 2 & 95.4 & 4.7 & 100.1 \\
\hline 4 & $\mathrm{~S}(1)$ as exsolved lamellae $\ldots \ldots \ldots \ldots \ldots \ldots$ & 2 & 93.7 & 3.8 & 97.5 \\
\hline 5 & A1 as exsolved lamellae $\ldots \ldots \ldots \ldots \ldots \ldots \ldots$ & 1 & 85.6 & 15.7 & 101.3 \\
\hline 6 & $S(2)$ as host for exsolved $S(1)$ and $A 1 \ldots \ldots \ldots \ldots$ & 2 & 91.6 & 8.1 & 99.7 \\
\hline \multirow[t]{2}{*}{7} & $S(3)$ as secondary alteration product $\ldots \ldots \ldots \ldots \ldots$ & 1 & 98.2 & 1.8 & 100.0 \\
\hline & Aggregate 2 (Plate 1f) & & & & \\
\hline 8 & 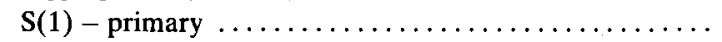 & 2 & 93.0 & 4.5 & 97.5 \\
\hline 9 & $\mathrm{~S}(1)$ as exsolved lamellae $\ldots \ldots \ldots \ldots \ldots \ldots \ldots$ & 2 & 92.5 & 4.6 & 97.1 \\
\hline 10 & A1 as exsolved lamellae $\ldots \ldots \ldots \ldots \ldots \ldots \ldots$ & 3 & 82.2 & 15.6 & 97.8 \\
\hline \multirow[t]{2}{*}{11} & $S(2)$ as host for exsolved $S(1)$ and $A 1 \ldots \ldots \ldots \ldots$ & 3 & 90.3 & 7.5 & 98.8 \\
\hline & Aggregate 3 & & & & \\
\hline 12 & A1 as exsolved lamellae & 1 & 85.9 & 14.1 & 100.0 \\
\hline 13 & $\mathrm{~S}(2)$ as host for exsolved A1 lamellae ..... & 2 & 93.8 & 5.0 & 98.8 \\
\hline
\end{tabular}

Analyses 1 and 2: sample GGU 150102b. Analyses 3-13: GGU 150102g

Hitachi microprobe. $30 \mathrm{kV}$. Standards were pure silver and bismuth. ZAF corrections according to a modified programme after Springer (1967)

crystallized earlier than the host cuprostibite during partial replacement of the loellingite crystals. Large amounts of small, equidimensional and subhedral loellingite crystals are concentrated locally in the cuprostibite. In one polished section such crystals were found not only in the cuprostibite but also in adjacent silver(1) (Plate $1 \mathrm{c}$ ). The distribution of the grains is not affected by the presence of the boundary between the two host minerals.

Sphalerite occurs in contact with most of the other ore minerals, sometimes forming a considerable portion of the ore aggregates. There are inclusions of silver(1) (Plate 1 d) and rohaite associated with cuprite. Chalcocite replacement veinlets often separate the sphalerite aggregate from silicate minerals and from other ore minerals.

Antimonian silver (three varieties) and allargentum are present in extremely small amounts precluding X-ray crystallographic examination. Their identification is based on optical properties and microprobe analyses. The minerals mostly occur 
enclosed in cuprostibite, sphalerite and silicate minerals. Three varieties of antimonian silver are referred to below as silver(1), silver(2) and silver(3). The first two varieties correspond to silver(1) and silver(2) described by Petruk et al. (1970, 1971). The composition of the silver phases is given in Table 3.

Silver(1) often contains inclusions of loellingite, rohaite, chalcocite, cuprostibite and/or cuprite (Plate $1 \mathrm{c}$; Table 3,1). A silver(1) grain enclosed in sphalerite was found to contain idiomorphic crystals of cuprostibite and cuprite (Plate $1 \mathrm{~d}$ ). Graphic intergrowth between silver(1) and one or more of the minerals cuprite, valentinite and cuprostibite have rarely been observed (Plate 1 e; Table 3,2).

Silver(2) contains exsolved lamellae of allargentum and silver(1) (Plate $1 \mathrm{f}, \mathrm{g}$ ). The silver(1) lamellae cut across the allargentum lamellae, sometimes displacing them, and are thus later than the allargentum. Alteration of silver(1), silver(2) and allargentum has resulted in the formation of silver(3) which encloses very fine-grained cuprite and senarmontite. Similar alteration of dyscrasite and allargentum from the Kangerdluarssuk cuprostibite locality is described in a later section.

The mineral relationships observed show that some of the silver-antimony mineral intergrowths were originally composed of two silver varieties. In Plate $1 \mathrm{f}$ euhedral crystals of silver(1) are shown; apparently silver(1) has remained stable down to room temperature, but the other more antimony-rich silver phase has apparently equilibrated by exsolution of allargentum. Still later, relatively small amounts of silver(1) were exsolved from this phase.

The simultaneous crystallization of silver(1) and silver(2) (e.g. 3.8 and 3.11 in Plate $1 \mathrm{f}$ ) is incompatible with the experimental results (Somanchi, 1966) which indicate that in the Ag-Sb system only one silver phase may crystallize, either alone or in association with allargentum.

The mineral relationships displayed in Plate $1 \mathrm{~g}$ closely resemble those between the three mercury-bearing Ag-Sb phases from Cobalt, Ontario, illustrated in Petruket al., (1971, fig. 127). Silver(2) (with 6.9-8.4\% $\mathrm{Sb}$ and $0.3-3.3 \% \mathrm{Hg}$ ) from this locality contains lamellae of allargentum (with $14.4-15.9 \% \mathrm{Sb}$ and $0.0-0.9 \% \mathrm{Hg}$ ) and silver(1) (with $0.8-5.3 \% \mathrm{Sb}$ and $0.4-8.1 \% \mathrm{Hg}$ ). Petruk et al. (1971) have interpreted these textural relationships as the result of the decomposition of an original silver-rich allargentum.

The similar textural relationships between silver(1), silver(2) and allargentum at Ilímaussaq and Cobalt, and the comparable antimony contents in the mineral phases, suggest that the phase relationships are not modified by the presence of small amounts of mercury. Silver(2) from both localities contains up to $8 \% \mathrm{Sb}$. Experimental results suggest that up to $6 \% \mathrm{Sb}$ may dissolve in silver at temperatures below $400^{\circ} \mathrm{C}$ (Somanchi, 1966). Petruk et al. (1971) assumed that the presence of mercury may have expanded the compositional field of the antimonian silver from Cobalt. The content of up to $8 \% \mathrm{Sb}$ in silver(2) from Ilimaussaq shows that this is not the case and suggests that the stability field of antimonian silver is broader than suggested by Somanchi (1966). However, the penecontemporaneous crystalliza- 
tion of two antimonian silver phases (Plate $1 \mathrm{f}$ ) within this part of the Ag-Sb system and the instability of one of these phases at lower temperatures clearly demonstrates our incomplete knowledge of the phase relationships in this part of the system.

The antimony content in allargentum associated with dyscrasite from the Kangerdluarssuk locality varies between 15.6 and $17.0 \%$, averaging $16.2 \%$. The content of antimony in allargentum exsolved from silver(2) in the Kvanefjeld locality is between 14.1 and $15.6 \%$, averaging $15.1 \%$. Allargentum from Cobalt contains between 14.4 and $15.9 \%$ antimony. These contents support the assumption by Petruk et al. (1970) that the stability field of allargentum is very narrow at room temperature (fig. 6).

\section{Discussion}

Copper-antimony minerals have been found at five localities within the Ilímaussaq intrusion. They represent the mineral association no. II described by Karup-Møller (1978). Ore minerals occur in relatively large quantities only at the Kangerdluarssuk locality, while at the other localities they are present as small scattered lumps which are generally less than one centimetre in size. Cuprostibite is the major ore mineral at three localities; at the other two localities native antimony, valentinite and senarmontite predominate (Karup-Møller, 1974).

$\mathrm{The} \mathrm{Cu}-\mathrm{Sb}$ minerals occur in late pneumatolytic-hydrothermal veins which intersect naujaite except at the Kvanefjeld occurrence where the veins occur along the contact of a trachyte dyke.

The ussingite-analcime-sodalite veins of the Taseq slope are genetically associated with a network of veins of fine-grained steenstrupine-arfvedsonite lujavrite (Engell et al., 1971). The occurrences at the Kangerdluarssuk and Tuperssuatsiait localities ( 2 and 4, fig. 1 ) are associated with pegmatite-rich lujavrite (Karup-Møller, 1974).

The Kvanefjeld occurrence is associated with late, medium to coarse-grained arfvedsonite lujavrite intersecting fine-grained arfvedsonite lujavrite; the two types of lujavrite appear separated in time by the emplacement of the trachyte dyke along which the $\mathrm{Cu}-\mathrm{Sb}$ minerals occur.

The field relations indicate that the $\mathrm{Cu}-\mathrm{Sb}$-minerals were deposited from late fluids expelled from consolidating lujavrite magma which was contaminated with material released during late recrystallization of earlier rocks, especially naujaites (cf. Sørensen, 1962). The mineralization also occurs within the lujavritic rocks.

The chalcophile elements in the ore minerals may thus be derived partly from trace elements concentrated in the primary rock-forming minerals and partly from incompatible elements concentrated in residual fluids.

The mineralization is dominated by $\mathrm{Cu}$ and $\mathrm{Sb}$, accompanied by minor $\mathrm{Pb}, \mathrm{Zn}$ and Ag; at the Taseq slope and Kvanefjeld thallium is also important. Arsenic is present only in loellingite. 
The agpaitic rocks of the Ilimaussaq intrusion have high average contents of sulphur and chalcophile elements: $\mathrm{S} 0.091 \%, \mathrm{Zn} 0.087 \%, \mathrm{~Pb} 0.023 \%$, Mo $0.0014 \%$, Sn $0.0115 \%$. The arfvedsonite lujavrites have the highest contents of these elements recorded so far, the maximum contents being: S $0.28 \%, \mathrm{Zn} 0.27 \%$, $\mathrm{Pb} 0.054 \%$, Sn $0.031 \%$, Mo $0.004 \%$ (Gerasimovsky, 1969). Gerasimovsky (1969) reports 2.5-264 ppm Cu. Preliminary analyses for Sb suggest that this element is present in amounts of less than $10 \mathrm{ppm}$ (personal communication, J. Rose-Hansen, February, 1977). The content of $\mathrm{Ag}$ in kakortokite is less than $2 \mathrm{ppm}$ and that of As between 4 and $10 \mathrm{ppm}$ according to preliminary data obtained by J. Bailey (personal communication, December, 1976).

Sphalerite and to some extent also galena are of widespread occurrence in the lujavrites and in the late hydrothermal veins. Sphalerite and troilite are common accessories in the naujaites. Other sulphide minerals are present in extremely small quantities.

The sulphides, native metals and their alloys were formed at exceptionally low sulphur fugacities due to the agpaitic nature of the Ilimaussaq magmas (Karup-Møller, 1978). The activity of volatiles (e.g. $\mathrm{H}_{2} \mathrm{O}, \mathrm{CO}_{2}, \mathrm{~F}, \mathrm{Cl}$ and $\mathrm{S}$ ) decreases sharply with increasing alkalinity of magmas, and the separation of volatiles is severely limited in agpaitic systems (Kogarko, 1974). Therefore, during crystallization the volatile elements to a large extent enter into the solid phases (sodalite-hackmanite, eudialyte, villiaumite, arfvedsonite and hydrous aluminosilicates). Sodalite is an early mineral in the naujaites and lujavrites and also in many of the late pneumatolytic-hydrothermal veins. According to Gerasimovsky (1969) sodalite contains an average of $0.13 \% \mathrm{~S}$ in the naujaites and $0.22 \% \mathrm{~S}$ in the associated pegmatites. Sulphur was therefore removed from the magma at an early stage explaining the scarcity of sulphides in rocks having high contents of sulphur.

A part of the early sodalite was decomposed during late magmatic and post-magmatic recrystallization of the rocks. Sulphur was set free while the sodalite was replaced by analcime and natrolite. This may explain the formation of at least some of the late, sparse sulphides.

The native metals and the sulphides crystallized in a system characterized by a very low oxygen fugacity. Similar conditions of crystallization of the rock-forming minerals have been discussed by Larsen (1976). Low oxygen fugacities are also evident from the presence of bituminous solids and hydrocarbon gases (Petersilie \& Sørensen, 1970).

At the two localities characterized by the occurrence of native antimony and antimony oxides (Karup-Møller, 1974), native antimony, valentinite and senarmontite formed first. During the final stages of crystallization, the formation of native antimony ceased and only that of valentinite (and associated sulphides) continued. Possibly, at the same time, the oxidation of early formed native antimony resulted in the formation of senarmontite.

At the Kvanefjeld cuprostibite locality cuprite, sometimes associated with valen- 
tinite or cuprostibite or both, crystallized in graphic intergrowth with antimonian silver. At the Kangerdluarssuk locality both cuprite and native copper occur in graphic intergrowth with dyscrasite and allargentum (Plate 2). An increase in the water content and therefore also in the oxygen fugacity during the crystallization of dyscrasite and allargentum is suggested by the gradual formation of mineral A, which has sometimes developed in graphic intergrowth with the two Ag-Sb alloys.

The relationships between cuprostibite and the associated ore minerals bear no evidence of the temperature of formation of these minerals. Fluid inclusion studies on the gangue minerals have not yet been attempted. However, the ore mineral aggregates with native antimony, antimony oxides and skinnerite at area ' $A$ ' in fig. 2 are considered to have crystallized at temperatures above $359^{\circ} \mathrm{C}$ (Karup-Møller \& Makovicky, 1974). This conclusion is based on the stability field of skinnerite which has been determined experimentally. According to Skinner et al. (1972) skinnerite is stable only at temperatures between $359^{\circ} \mathrm{C}$ and $607^{\circ} \mathrm{C}$ in the condensed $\mathrm{Cu}-\mathrm{Sb}-\mathrm{S}$ system. At the Kangerdluarssuk locality the cuprostibite occurrence is situated about $15 \mathrm{~m}$ from the skinnerite occurrence (fig. 2). As the two types of ore mineralizations are associated with similar gangue minerals a common origin of the mineralizing fluids may be assumed (Karup-Møller, 1974). Cuprostibite and associated minerals may therefore have crystallized at similar high temperatures as the skinnerite paragenesis, i.e. at temperatures in the range of $360-400^{\circ} \mathrm{C}$. As discussed by Karup-Møller (1974) the pressure of formation may have been around 2000 bars. These estimates are in accordance with those presented by Sørensen (1969).

The secondary minerals are considered to be supergene, although this cannot be definitely proved on the basis of their textural relationships.

'Sb-malachite' appears to be of supergene origin, as it is only known from the surface of the outcrops of cuprostibite.

Connellite, linarite and brochantite are elsewhere known as typical supergene minerals. The mode of occurrence of covellite, and blaubleibender covellite, and of the hydrated cuprites with frequent 'gel-structures', and the replacement of galena by copper sulphides and cerussite (hydrocerussite), all suggest a supergene origin of the secondary minerals.

The origin of the secondary minerals after dyscrasite and allargentum is, in analogy with the origin of the other alteration minerals, considered supergene.

The crystallization of allargentum and dyscrasite under increasing water concentrations and oxygen fugacities may lead to the hypogene formation of cuprite and mineral $\mathrm{A}$ as inclusions in the Ag-Sb alloys. It may be that continued increase in content of water and oxygen fugacity has caused the decomposition of earlier crystallized ore minerals. At the Kvanefjeld locality the most Sb-rich Ag-Sb minerals are the most intensively altered.

The alteration of dyscrasite and allargentum at the Kangerdluarssuk locality is considered to be accompanied by the decomposition of cuprostibite. Copper derived from decomposed cuprostibite was bound in cuprite and native copper, which 
occur as inclusions in antimonian silver. Since the alteration of the cuprostibite into Sb-malachite is considered to be supergene in origin, the alteration of all the $\mathrm{Cu}-\mathrm{Sb}-\mathrm{Ag}$ minerals may accordingly also be supergene.

The decomposition of rohaite into digenite intergrown with senarmontite may either be supergene or hypogene in origin.

The rather intensive supergene alterations are remarkable in this rather recently deglaciated region which has ever since been exposed to an arctic climate. 


\title{
PRIMARY AND SECONDARY ORE MINERALS ASSOCIATED WITH CUPROSTIBITE*
}

\author{
Sven Karup-Møller \\ Dyscrasite, allargentum and associated minerals at \\ the Kangerdluarssuk cuprostibite locality
}

\begin{abstract}
Introduction
The following primary ore minerals are associated with cuprostibite at the Kangerdluarssuk locality (fig. 1): dyscrasite, allargentum, galena, sphalerite, cuprite, native copper and an unnamed mineral, here described as mineral A. Mineral A may possibly be a bindheimite variety. Several secondary minerals (antimonian silver, cuprite, native copper, senarmontite, chalcocite and digenite) formed during alteration of the primary ore minerals.
\end{abstract}

\section{Mineral descriptions}

\section{Dyscrasite}

Dyscrasite is generally granular with a grain size ranging from 0.1 to $0.5 \mathrm{~mm}$. The orthorhombic cell dimensions (refined on the basis of Guinier powder film No. 1608 from sample GGU $151530.772-4$ ) are: $a$ 2.993 $\pm 0.04 \AA, b$ 5.189 \pm 0.006 $\AA$ and $c 4.812 \pm 0.002 \AA$. (Those for dyscrasite from Cobalt, Ontario, published by Petruk et al., 1971, are: $a 2.987 \AA, b 5.178 \AA$ and $c 4.794 \AA$ ). Microprobe analyses (plotted on fig. 6) of eight mineral grains gave the following results in weight per cent: $\mathrm{Ag} \mathrm{76.6-79.3,} \mathrm{average} \mathrm{78.3,} \mathrm{and} \mathrm{Sb} 21.1-23.8$, average 22.5, leading to the formula $\mathrm{Ag}_{0.80} \mathrm{Sb}_{0.20}$. (Standard material used was a synthetic alloy with the composition 75.995 per cent silver and 24.005 per cent antimony).

\section{Allargentum}

Allargentum (redefined by Petruk et al., 1970) is always enclosed in dyscrasite and is estimated to constitute around five per cent of the area occupied by the latter mineral. Its maximum grain size is $0.1 \mathrm{~mm}$. It generally forms a very irregular intergrowth with dyscrasite (Plate $2 \mathrm{~b}$ ). The mineral could not be isolated for X-ray examination. Microprobe analyses (plotted on fig. 6) on five grains gave the following results in weight per cent: $\mathrm{Ag} 83.0-85.1$ (average 83.8) and $\mathrm{Sb}$ 15.6-17.0 (average 16.2) leading to the formula $\mathrm{Ag}_{0.86} \mathrm{Sb}_{0.14}$. (Standard material used was an alloy with the composition 89.987 per cent silver and 10.013 per cent antimony).

\section{Antimonian silver}

Antimonian silver with a grain size ranging from 0.001 to $0.1 \mathrm{~mm}$ is granular and has developed from alteration of dyscrasite and allargentum (Plates 2 and 3). The mineral always contains abundant, very fine-grained inclusions of one or more of

* Contribution to the mineralogy of Ilímaussaq no. 47. 


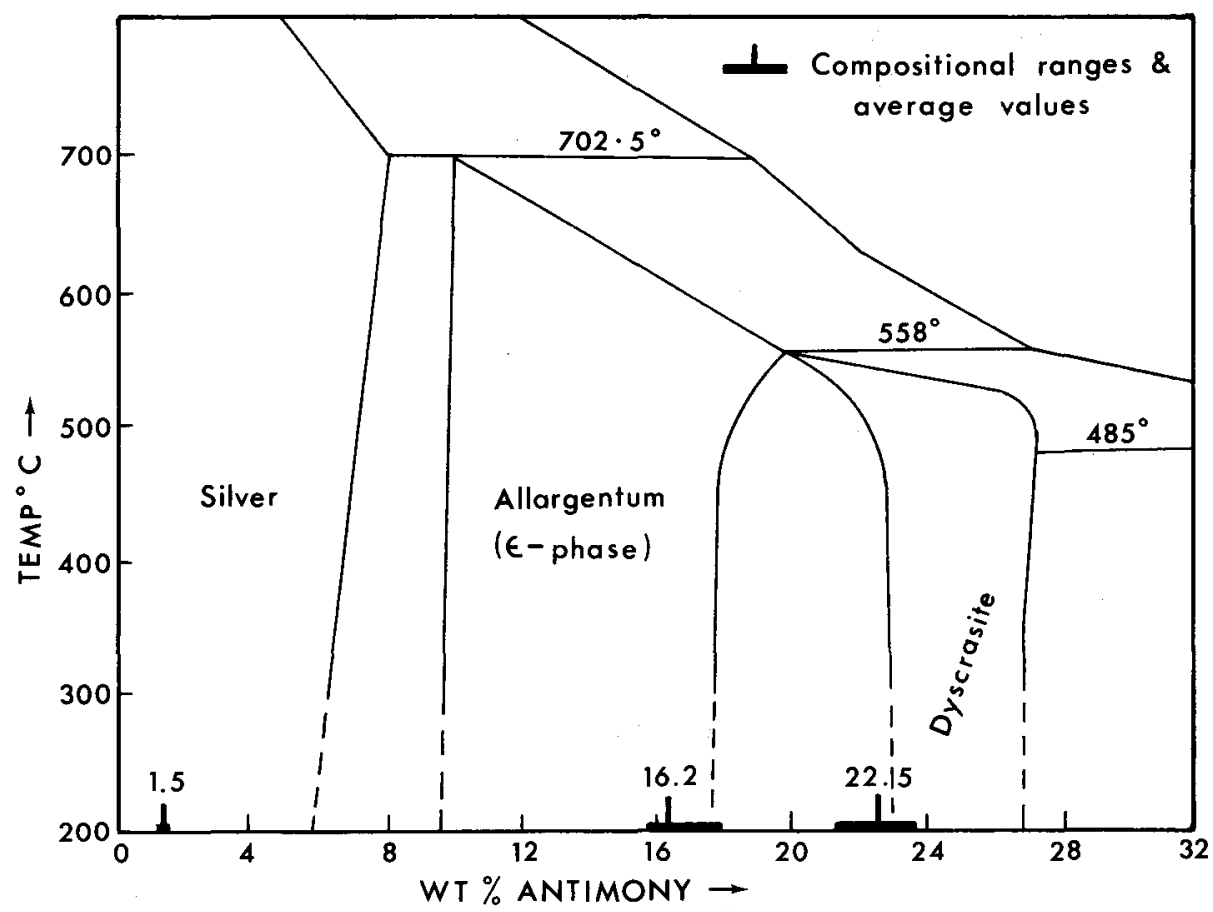

Fig. 6. Ag-Sb phase diagram taken from Petruk et al., 1970, showing compositional range and average composition of the three silver-antimony minerals, dyscrasite, allargentum and antimonian silver.

the following minerals: native copper, cuprite and senarmontite. Microprobe analyses of two grains gave an antimony content of 1.3 and 1.6 per cent by weight. A weak anisotropism under crossed nicols is presumably caused by the low antimony content (Peacock, 1940).

\section{Galena}

Microprobe examination of galena failed to detect any silver and antimony, although the mineral occurs in contact with contemporaneously crystallized dyscrasite.

\section{Sphalerite}

Sphalerite does not contain iron in amounts detectable by the microprobe.

\section{Mineral $A$}

Mineral A, which does not correspond to any previously described mineral, is present as less than $0.1 \mathrm{~mm}$ small, irregularly shaped grains enclosed in dyscrasite (fig. 7 and Plates 2 b, $3 \mathrm{~b}$, c). The small grain size of the mineral has prevented a complete mineralogical examination. 


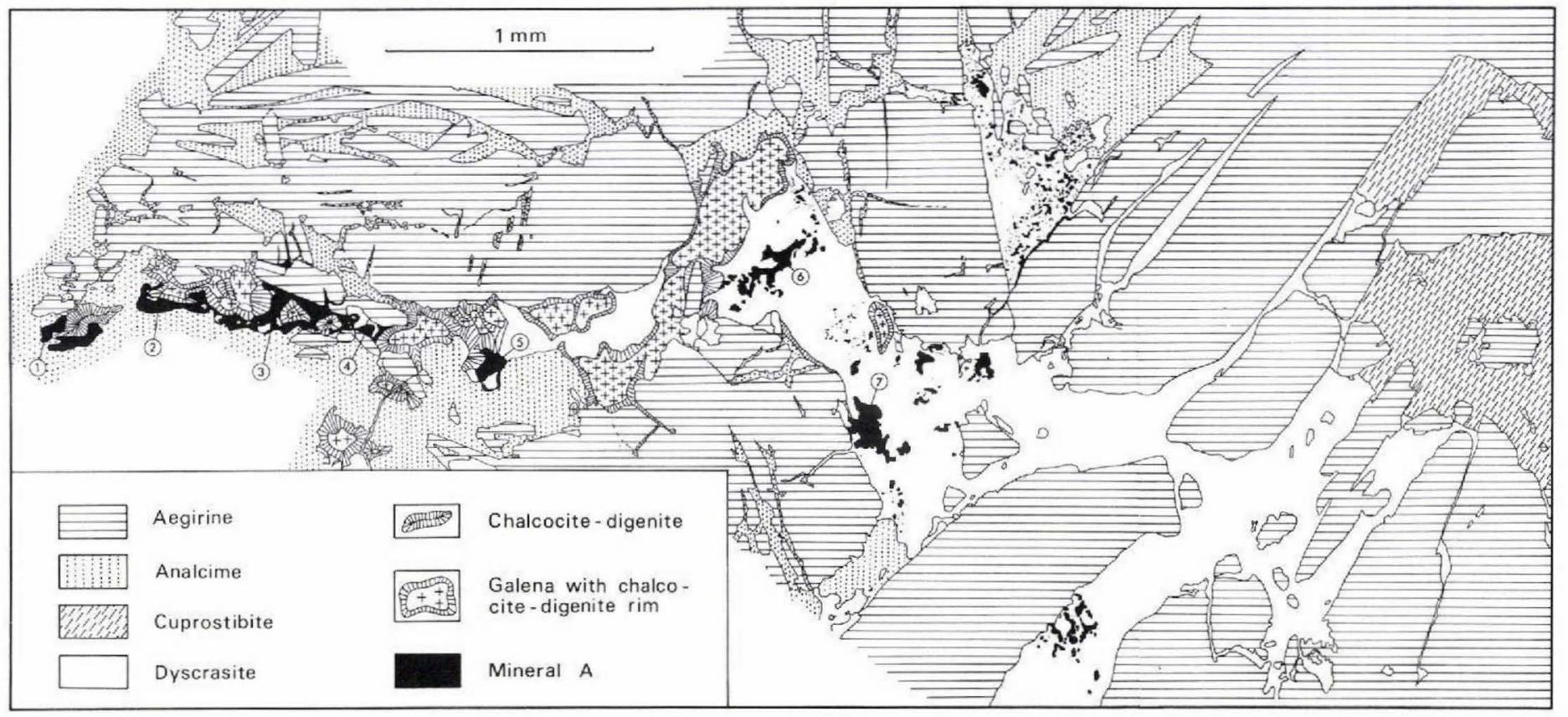

Fig. 7. Dyscrasite-dominated veinlet in aegirine adjacent to a few centimetres large cuprostibite area. For detailed explanation see the text. Sample GGU $151530.772-4$. 
Table 4. Microprobe analyses on mineral $A$

\begin{tabular}{|c|c|c|c|c|c|c|c|c|c|}
\hline & 1 & 2 & 3 & 4 & 5 & 6 & 7 & \multicolumn{2}{|c|}{ Average values } \\
\hline $\mathrm{Cu}$ & 3.3 & 2.6 & 3.9 & 7.3 & 3.2 & 5.2 & 0.7 & $3.7)$ & \multirow{2}{*}{40.2} \\
\hline $\mathrm{Sb}$ & 35.1 & 37.5 & 38.0 & 32.3 & 38.1 & 34.7 & 39.8 & 36.5 & \\
\hline $\mathrm{Pb}$ & 32.3 & 30.9 & 31.4 & 30.2 & 30.8 & 34.6 & 34.0 & 32.0 & \multirow{4}{*}{33.2} \\
\hline $\mathrm{Fe}$ & 1.1 & 0.7 & 0.8 & 0.8 & 0.7 & 0.6 & 0.5 & 0.7 & \\
\hline $\mathrm{Ca}$ & 0.6 & 0.4 & 0.3 & 0.3 & 0.3 & 0.7 & 0.6 & 0.5 & \\
\hline $\mathrm{Si}$ & 2.1 & 2.2 & 2.1 & 2.4 & 2.2 & 2.4 & 1.6 & 2.1 & \\
\hline \multirow[t]{2}{*}{$\mathrm{O}$} & 12.7 & 13.0 & 13.1 & 12.7 & 13.1 & 13.4 & 12.8 & 13.0 & \\
\hline & 87.2 & 87.3 & 89.6 & 86.0 & 88.1 & 91.6 & 90.0 & 88.5 & \\
\hline $\mathrm{Cu}$ & 3.7 & 2.9 & 4.3 & 8.1 & 3.5 & 5.5 & 0.8 & $4.1\}$ & \multirow{3}{*}{25.1} \\
\hline $\mathrm{Sb}$ & 20.6 & 21.8 & 21.7 & 18.5 & 22.0 & 19.2 & 23.5 & $21.0\}$ & \\
\hline $\mathrm{Pb}$ & 11.1 & 10.6 & 10.5 & 10.2 & 10.5 & 11.3 & 11.8 & 10.9 & \\
\hline $\mathrm{Fe}$ & 1.4 & 0.9 & 1.0 & 1.0 & 0.9 & 0.8 & 1.1 & 1.0 & \multirow{4}{*}{12.7} \\
\hline $\mathrm{Ca}$ & 1.1 & 0.7 & 0.5 & 0.5 & 0.4 & 1.2 & 1.0 & 0.8 & \\
\hline $\mathrm{Si}$ & 5.2 & 5.6 & 5.2 & 6.1 & 5.4 & 5.8 & 4.2 & 5.3 & \\
\hline \multirow[t]{2}{*}{$\mathrm{O}$} & 56.7 & 57.5 & 56.8 & 55.6 & 57.3 & 56.2 & 57.6 & 57.1 & \\
\hline & 100.0 & 100.0 & 100.0 & 100.0 & 100.0 & 100.0 & 100.0 & 100.0 & \\
\hline
\end{tabular}

The seven mineral A grains analyzed are shown in fig. 7. Sample GGU 151530.772-4

The values for oxygen have been calculated. Standards were $\mathrm{Cu}, \mathrm{Sb}, \mathrm{Fe}, \mathrm{PbS}$ and oligoclase.

In polished section mineral $\mathrm{A}$ is isotropic and dark grey to black in colour. Internal reflections under crossed nicols are light yellowish brown. Microprobe analyses on the seven numbered grains shown in fig. 7 are listed in Table 4 . The analyses suggest that copper is substituted by antimony. The small amounts of iron and calcium may substitute for lead. The oxygen values have been determined by calculation. The deviation from 100 of the sum of the average weight per cent values is 11.5. This suggests that the mineral is not a pure oxide but either a hydroxide or a hydrated hydroxide. The following formula is suggested:

$(\mathrm{Sb}, \mathrm{Cu})_{2}(\mathrm{~Pb},(\mathrm{Fe}, \mathrm{Ca})) \mathrm{Si}_{0.4}\left(\mathrm{O}, \mathrm{OH}, \mathrm{H}_{2} \mathrm{O}\right)_{y},(y \approx \max .9 .6)$.

The chemical composition of mineral $\mathrm{A}$, its isotropism and its yellow brown internal reflections suggest that it represents a bindheimite variety. Bindheimite $\left(\mathrm{Pb}_{1-2} \mathrm{Sb}_{2-1}\left(\mathrm{O}, \mathrm{OH}, \mathrm{H}_{2} \mathrm{O}\right)_{6-7}\right)$ belongs to the stibiconite group of minerals, which generally form by the alteration of $\mathrm{Cu}-\mathrm{Sb}$ sulphides. The variety 'monimolite' is metamorphic (Igelström, 1865; Mason \& Vitaliano, 1953). Mineral A differs from bindheimite by its significant amounts of $\mathrm{Si}$. The mineral when observed in reflec- 
ted light appears to be homogeneous and composed of only one phase. Si must therefore be contained in mineral $\mathrm{A}$, and does not represent impurities of other minerals.

\section{Chalcocite and digenite}

These two minerals have crystallized during alteration of galena (Plates 3 and 4). They have been identified by their optical properties and microprobe tests. The two minerals occur in too small amounts to be isolated for X-ray investigation.

Native copper and cuprite

Both minerals have been found enclosed in antimonian silver (Plate $2 \mathrm{c}, \mathrm{d}$ ), and dyscrasite (Plate 2 a).

\section{Senarmontite}

A mineral with very low reflectivity occurs as equidimensional, isotropic grains with an average size of $0.03 \mathrm{~mm}$ enclosed in antimonian silver (Plate $3 \mathrm{~d}$ ). Microprobe analyses suggest that the only metal contained in the mineral is antimony. The mineral does not break down under the impact of the electron beam. It may therefore be either senarmontite or valentinite. In reflected light senarmontite is dark grey $(R \sim 12.4)$ and isotropic, while valentinite is grey $(R \sim 14.1-16.3)$ and anisotropic. It is therefore assumed that the mineral in the antimonian silver is senarmontite.

\section{Mineral relationships}

\section{Primary minerals}

Mode of occurrence of dyscrasite

Dyscrasite occurs in sparse amounts enclosed in cuprostibite. The major portion of the dyscrasite occurs in the silicate minerals, preferably along fractures in aegirine adjacent to cuprostibite or within a few millimetres from this mineral. Some dyscrasite forms thin veinlets along contacts between cuprostibite and silicate minerals. The veinlets are often extensions of larger dyscrasite grains along the same contact.

Dyscrasite enclosed in gangue forms the host for allargentum, galena and mineral A. A rather spectacular mode of occurrence of dyscrasite and associated minerals along a fracture in sample GGU $151530.772-4$ is sketched in fig. 7.

The fracture extends away from a one centimetre large cuprostibite aggregate with a size of about one centimetre. The aggregate is enclosed in aegirine and lies to the right in fig. 7. The fracture breaks across some aegirine grains and follows the contact between others. The first short section of the fracture is filled with cuprostibite which forms part of the adjacent cuprostibite area. The cuprostibite is 
soon followed by dyscrasite. The content of galena and mineral $\mathrm{A}$ in the dyscrasite increases with increasing distance from the cuprostibite. Very small amounts of primary cuprite have crystallized in association with mineral A. Analcime-filled replacement veinlets may have formed simultaneously with the crystallization of dyscrasite in the adjacent pyroxene. Finally dyscrasite is absent from the veinlet and the minerals present are galena and mineral $\mathrm{A}$ both lying along the contact between aegirine and analcime. A few galena grains form inclusions in the analcime.

The position of the fracture vein, resembling an offset from the cuprostibite area, suggests that the cuprostibite crystallized before the vein minerals. Those closest to the cuprostibite area may have crystallized earlier than those at a greater distance from the area.

Rarely dyscrasite enclosed in silicate minerals contains irregularly shaped grains of native copper (Plate 2 a).

\section{The allargentum-dyscrasite relationships}

Allargentum always forms irregularly shaped inclusions in dyscrasite (Plate $2 \mathrm{~b}$ ). The relationships between the two minerals suggest that they crystallized simultaneously.

\section{The mineral $A-$ dyscrasite relationships}

The major portion of mineral $\mathrm{A}$ is enclosed in dyscrasite. Its distribution along the dyscrasite-filled fracture shown in fig. 7 is characteristic of its mode of occurrence. The individual grains are irregularly shaped and they occur in groups of a few or many (Plate $2 \mathrm{~b}$ and Plate $3 \mathrm{c}$ ). The mineral sometimes forms graphic intergrowths with the dyscrasite host, indicating that the two minerals crystallized simultaneously (Plate $3 \mathrm{c}$ ). Similar intergrowth characterizes dyscrasite and cuprite (Plate $2 \mathrm{~d}$ ), and dyscrasite and native copper (Plate $2 \mathrm{a}$ ). Grains of cuprite may be intergrown with mineral A. Rarely mineral A has crystallized outside dyscrasite as shown at the left in fig. 7 where it is intimately associated with galena.

\section{Crystallization sequence of the primary minerals}

A schematic crystallization sequence of the primary minerals, based especially on the relationships observed between gangue and metallic minerals in fig. 7 , is illustrated in fig. 8 . The crystallization sequence suggests the following change in the composition of the mineralizing fluids as the crystallization progressed. After the formation of the cuprostibite the rest-fluids were enriched in silver. This element was then precipitated together with antimony as dyscrasite and allargentum. Gradually the rest-fluids became enriched in lead and sulphur, and galena crystallized. The formation of mineral A suggests an increasing water content of the fluids. 


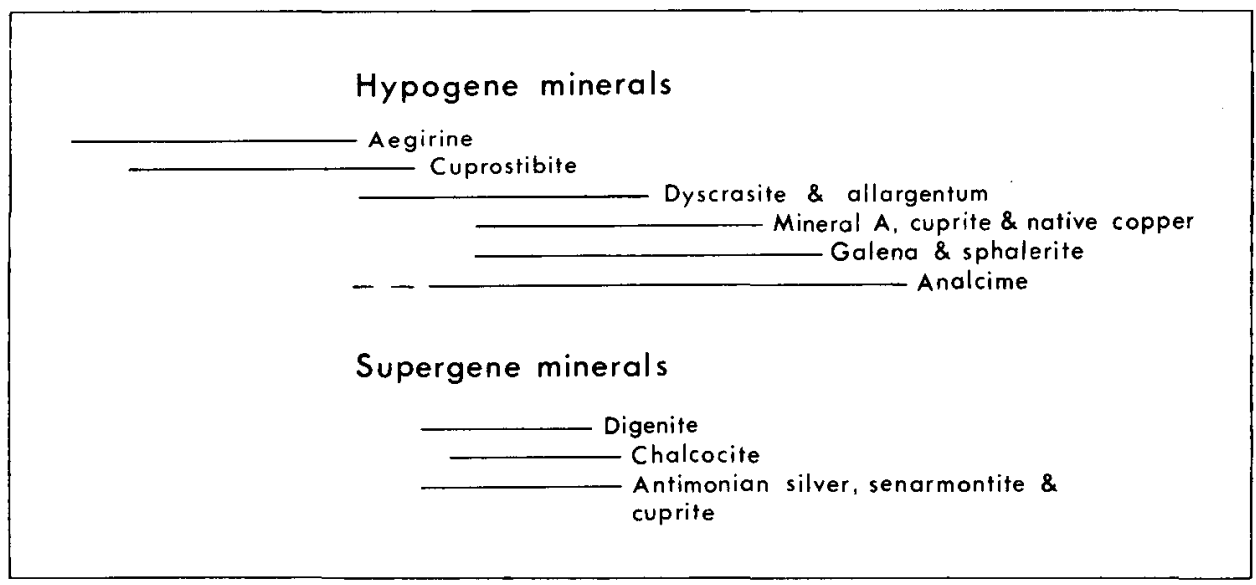

Fig. 8. Crystallization sequence of the ore minerals at Kangerdluarssuk.

\section{Secondary minerals}

\section{Alteration of dyscrasite and allargentum}

Alteration of dyscrasite and the rarely associated allargentum has resulted in the formation of antimonian silver containing only a few per cent antimony. The major portion of the released antimony was either bound as senarmontite or completely removed from the altered areas. Alteration of dyscrasite grains began from the contact and penetrated the dyscrasite grains in an irregular fashion, sometimes as a network of irregular veinlets.

Antimonian silver always contains inclusions of either cuprite or senarmontite or both (Plates 2 and 3). Graphic intergrowth between cuprite and antimonian silver is rare (Plate $2 \mathrm{~d}$ ). Sometimes native copper is also present (Plate $3 \mathrm{e}$ ). Copper in dyscrasite is not detectable by the microprobe. The copper bound in the secondary cuprite and the secondary native copper enclosed in the antimonian silver must therefore originate from an external source. This is considered to be cuprostibite which presumably has been altered at the same time as the dyscrasite.

\section{Galena and associated secondary minerals}

Galena is rarely observed as inclusions in cuprostibite. Relatively more galena is present as scattered grains in dyscrasite or as aggregates of several grains in contact with dyscrasite (fig. 7). Galena is rarely embedded in mineral A (fig. 7). It has also crystallized along thin fractures in aegirine (Plate 3 a) or as isolated grains in analcime (Plate 4 a, c). 
All grains of galena are partially or completely replaced by digenite and chalcocite. In the case of partial replacement the mineral is surrounded by a band of variable thickness composed of the two secondary sulphides (Plate $4 \mathrm{a}-\mathrm{c}$ ). Digenite always forms a thin rim separating galena from chalcocite.

The area with galena, digenite and chalcocite present at the right hand side of Plate $4 \mathrm{a}$, is shown enlarged in plate $4 \mathrm{~b}$. Here homogeneous chalcocite with a few irregular cracks forms a rim around chalcocite with a regularly developed fracture pattern. The fractures are parallel to the galena cleavage directions along which digenite has developed. Plate $2 \mathrm{c}$, d shows galena grains which have been completely altered to a core of chalcocite with a regularly developed fracture pattern, surrounded by a rim of smooth chalcocite without fractures. When surrounded by antimonian silver the rim of copper sulphides around galena sometimes contains fine-grained antimonian silver (Plate $3 \mathrm{~d}$ ). Completely replaced galena may now consist of grains of homogeneous chalcocite with a regularly developed fracture pattern (Plate $3 \mathrm{a}$ ); the distinctly marked chalcocite grain boundaries no doubt represent the original galena grain boundaries. All the galena inclusions in cuprostibite have been completely replaced by chalcocite characterized by the regularly developed fracture pattern. A very heterogeneous chalcocite pseudomorph is shown in Plate $4 \mathrm{~d}$; the weakly reflecting materials forming concentrations mainly along the margins of the original galena aggregate consist either of one or a mixture of several unidentified $\mathrm{Cu}-\mathrm{Sb}$-hydroxides.

\section{Mode of formation of digenite and chalcocite}

Replacement of the galena must have involved the gradual exchange of lead by copper. This process requires the movement of both metals through earlier formed copper sulphides. The mineral relationships indicate that digenite crystallized during replacement of galena. As replacement progressed inward into the galena, the outer portion of the digenite rim changed into chalcocite presumably due to decreasing sulphur fugacity. This change was accompanied by the development of fractures in the chalcocite parallel to the original galena cleavage directions.

The copper is presumably derived from altered cuprostibite. As the alteration of this mineral progressed, copper was removed and crystallized as cuprite in adjacent silicate minerals. Secondary digenite and chalcocite only developed when migrating copper-bearing fluids came in contact with galena.

\section{Mode of occurrence of sphalerite}

Sphalerite is very rare. It occurs associated with galena or enclosed in silicate minerals. A chalcocite replacement rim generally surrounds the sphalerite grains (Plate 3 a). 


\section{Formation of primary and secondary ore minerals}

A large number of hydrothermal veins, characterized essentially by the minerals natrolite, analcime, sodalite, ussingite and/or alkali feldspars occur within the Ilimaussaq intrusion. They are considered to have crystallized from solutions, which were derived from the lujavrite magma as this crystallized. Sørensen (1962) assumes that the lujavrite magma crystallized at temperatures around $400^{\circ} \mathrm{C}$ and at a pressure of a few thousand bars. A temperature of formation of between 400 and $500^{\circ} \mathrm{C}$, based on experimental results, has been proposed by Piotrowski \& Edgar (1970). The maximum temperature of formation of the veins of the intrusion is therefore considered to have been around $400^{\circ} \mathrm{C}$.

The formation of the galena and dyscrasite alteration minerals and of the minerals developed by the alteration of cuprostibite (malachite, cuprite, senarmontite and native copper), are considered supergene, post-glacial in age and still active at present.

\section{Rohaite, a new thallium sulphide}

\section{Introduction}

Two thallium-bearing sulphides, chalcothallite and rohaite, have been found in the Ilímaussaq intrusion. Chalcothallite was described by Semenov et al. (1967). A determination of the crystal structure of the mineral is in progress.

Chalcothallite occurs in very small amounts as platy, micaceous aggregates a few centimetres across in ussingite veins at the Taseq chalcothallite and cuprostibite type locality (fig. 1).

The new mineral rohaite was found at the Kvanefjeld cuprostibite locality (samples GGU 150102 and 151102). Partial alteration of this mineral has resulted in the formation of finely intergrown digenite and senarmontite.

Rohaite was approved as a new mineral by the Commission for New Minerals and Mineral Names in September 1973. The mineral has been named after John Rose-Hansen (ro-haite), lecturer at the University of Copenhagen. The type material is kept at the Geological Museum, University of Copenhagen.

\section{Mode of occurrence}

Rohaite occurs in an analcime-sodalite-rich vein associated with cuprostibite, chalcocite, sphalerite, cuprite, loellingite, and antimonian silver. Digenite is also present in the vein, but does not occur in contact with rohaite. The ore minerals occur in patchy aggregates, rarely exceeding half a centimetre in size, in and between the silicate minerals. The mineralogical composition of the individual aggregates varies. The mineralogy of both ore and silicate minerals is described above. Here only the aggregates containing rohaite will be considered. 
Some aggregates are dominated by rohaite in random orientation. The rohaite is partly altered into a submicroscopic intergrowth of digenite and senarmontite (Plate 5 a, c, d). Chalcocite occurs interstitial to the rohaite grains. Some aggregates are separated from silicate minerals by a rim of chalcocite. Rarely the chalcocite rim increases in thickness, and it thus gradually changes into massive chalcocite enclosing partly altered rohaite crystals (Plate 5 a).

Chalcocite often occurs interstitial to the silicate minerals. Rarely, isolated rohaite crystals or crystal clusters lie randomly enclosed in this chalcocite.

Rohaite intergrown with chalcocite (Plate $5 \mathrm{~b}$ ) has been found enclosed in antimonian silver (variety silver-1) together with loellingite, cuprostibite and primary cuprite.

Aggregates of sphalerite may contain crystals or crystal clusters of partly altered rohaite. In some places cuprite is associated with the rohaite. Rims of late chalcocite have developed along grain boundaries in sphalerite aggregates and along contacts of sphalerite and rohaite or cuprite. The chalcocite rims may expand into relatively large chalcocite areas in contact with the sphalerite. The sphalerite is thus penetrated by chalcocite, establishing the age relationships between the two minerals.

Rohaite grains have also been observed along the contact between cuprostibite and sphalerite.

\section{Mineralogical properties}

Rohaite is tetragonal and occurs as subhedral to euhedral crystals (Plate 5 a). The grain size ranges from 0.05 to $0.5 \mathrm{~mm}$ and is on average $0.1 \mathrm{~mm}$.

Rohaite is optically positive in the visible spectrum. The reflectance pleochroism is distinct to strong in air and oil. Reflectance measurements at the four principal wave lengths are listed in Table 5.

In reflected light the mineral, in its darkest position, is dull bluish-grey, sometimes with a slight purple tint. In the brightest position it is yellowish cream.

The anisotropism under crossed nicols is very strong both in air and in oil. The colours are yellowish cream to black. Dark red-purple to brown colours are present near the positions of extinction when the nicols are not completely crossed.

Etching for one minute with the following reagents gave negative results: $\mathrm{HgCl}_{2}$

Table 5. Reflectance data for rohaite

\begin{tabular}{lllll}
\hline$\lambda_{\mathrm{nm}}$ & 481 & 546 & 590 & 650 \\
\hline$R_{\mathrm{g}}$ & 32.0 & 32.4 & 32.0 & 31.8 \\
$R_{\mathrm{p}}$ & 24.5 & 22.3 & 21.8 & 20.8 \\
\hline
\end{tabular}

Instrument: Leitz-MPV. Standard: $\mathrm{SiC}$ no. 85 Sample GGU 151102.1331. Measurements in air 
$(5 \%), \mathrm{KOH}(40 \%), \mathrm{KCN}(20 \%)$, and $\mathrm{FeCl}_{3}(20 \%)$. With $\mathrm{HCl}(1: 1)$ the polished surface turns slightly steel-bluish grey without being destroyed. With $\mathrm{HNO}_{3}(1: 1)$ the polished surface is destroyed and the mineral turns pitch black.

Microindentation hardness determined on ten grains varied from 88 to 103, averaging $94\left(\mathrm{VHN}_{25} \mathrm{~g}\right)$.

Guinier powder data on rohaite are listed in Table 6. Combined Weissenberg and precession studies have shown that the mineral is tetragonal. The following cell dimensions have been refined on the basis of the Guinier powder data, using the REFBASE III programme: $a 3.801 \pm 0.001 \AA, c 20.986 \pm 0.008 \AA$.

A supercell with the $a$ cell dimensions doubled characterizes the mineral. No systematic extinctions were observed in the Weissenberg photographs.

Microprobe analyses (Table 7) were made on seven rohaite grains in the same aggregate in sample GGU 151102.1331 from which material for the X-ray crystallographic examination was also isolated. Probe analyses were also completed on eight grains enclosed in chalcocite in sample GGU $151102 \mathrm{~h}$. The analyses suggest the following average composition of the mineral:

$$
\mathrm{TlCu}_{5} \mathrm{SbS}_{2}(Z=2)
$$

The number of sulphur atoms in the formula is less than that which corresponds stoichiometrically to the number of metal atoms assuming the presence of a normal sulphide. The standard used for the sulphur determinations listed in Table 4 was

Table 6. Guinier powder data for rohaite

\begin{tabular}{rccc}
\hline I & $\begin{array}{c}\mathrm{d}_{\text {hk1 }} \\
\text { (measured) }\end{array}$ & $\begin{array}{c}\mathrm{d}_{\text {hkl }} \\
\text { (calculated) }\end{array}$ & Indices \\
\hline 1 & 5.235 & 5.247 & 004 \\
9 & 3.800 & 3.801 & 010 \\
2 & 3.570 & 3.573 & 012 \\
4 & 3.498 & 3.498 & 006 \\
10 & 3.078 & 3.078 & 014 \\
3 & 2.681 & 2.687 & 110 \\
5 & 2.623 & 2.623 & 008 \\
5 & 2.605 & 2.603 & 112 \\
5 & 2.577 & 2.574 & 016 \\
10 & 2.393 & 2.392 & 114 \\
5 & 2.158 & 2.159 & 018 \\
9 & 1.902 & 1.900 & 020 \\
5 & 1.877 & 1.877 & 118 \\
4 & 1.749 & 1.749 & 00.12 \\
3 & 1.689 & 1.670 & 120 \\
5 & 1.618 & 1.617 & 124 \\
\hline
\end{tabular}

$\mathrm{CuK} \alpha_{1}$, Film no. 2170

Sample GGU 151102.1331 
Table 7. Microprobe analyses on rohaite

\begin{tabular}{|c|c|c|c|c|c|}
\hline & \multicolumn{2}{|c|}{$\begin{array}{l}\text { Average of } 7 \text { grains } \\
\text { from } 151102.1331\end{array}$} & \multicolumn{3}{|c|}{$\begin{array}{l}\text { Average of } 8 \text { grains } \\
\text { from } 151102 \mathrm{~h}\end{array}$} \\
\hline & Wt. \% & $\begin{array}{l}\text { Atom } \\
\text { ratio }\end{array}$ & Wt. \% & $\begin{array}{l}\text { Atom } \\
\text { ratio }\end{array}$ & \\
\hline $\mathrm{Tl}$ & $26.6 \pm 0.3$ & 0.965 & $27.7 \pm 0.2$ & $0.969]$ & \\
\hline Sb $\ldots$. & $41.0 \pm 0.6$ & 1.134 & $43.5 \pm 0.8$ & 1.045 & \\
\hline $\mathrm{Cu} \ldots \ldots \ldots$ & $18.6 \pm 0.2$ & 4.789 & $17.8 \pm 0.4$ & 4.893 & 7 \\
\hline $\mathrm{Pb} \ldots \ldots \ldots \ldots \ldots \ldots \ldots$ & $2.0 \pm 0.1$ & 0.040 & $1.6 \pm 0.1$ & 0.039 & \\
\hline $\mathrm{Fe} \ldots \ldots \ldots \ldots \ldots \ldots$ & $0.3 \pm 0.1$ & 0.072 & $0.3 \pm 0.2$ & 0.055 & \\
\hline $\mathrm{s} \ldots \ldots \ldots \ldots \ldots \ldots \ldots$ & $\frac{9.3}{97.8} \pm 0.2$ & 2.152 & $\frac{9.6}{100.5} \pm 0.2$ & 2.140 & \\
\hline
\end{tabular}

Standards were $\mathrm{PbS}$ (for lead), $\mathrm{CuFeS}_{2}, \mathrm{Tl}$ and $\mathrm{Sb}$

natural chalcopyrite. The sulphur contents were also determined against chalcocite which in sample GGU $151102 \mathrm{~h}$ occurs as a host for the analyzed rohaite grains. The following results were obtained with the latter standard confirming the sulphur determinations in Table 7: 9.2 $\pm 0.2 \% \mathrm{~S}$ for rohaite sample GGU 151102.1331 and $9.5 \pm 0.2 \% \mathrm{~S}$ for the mineral in sample GGU $151102 \mathrm{~h}$.

Material could not be isolated for density determination. The calculated density based on the experimentally determined formula is $7.780 \mathrm{~g} / \mathrm{cm}^{3}$ and that based on the ideal formula is $7.752 \mathrm{~g} / \mathrm{cm}^{3}$.

\section{Alteration of rohaite}

Rohaite, especially when enclosed in silicate minerals ( Plate $5 \mathrm{c}$ ), has been partly to completely altered into a mixture of digenite and senarmontite. Generally the rohaite grains show a narrow, coloured rim against the secondary minerals (Plate $5 \mathrm{c}$ ). This rim presumably represents the first step in the alteration of rohaite. However, microprobe analyses failed to disclose any difference in the chemical compositions of the rim and the central areas of rohaite grains.

Cracks filled with an unidentified transparent mineral are often developed parallel to (001) in partly altered rohaite grains (Plate $5 \mathrm{a}, \mathrm{c}$ ). Larger, slightly altered rohaite areas contain these fracture fillings only in their marginal parts.

In spite of careful polishing the secondary digenite and senarmontite never acquire the normal smooth and shiny surface of a sulphide. The surface is dull in appearance as if etched (Plate $5 \mathrm{a}, \mathrm{c}$ ). Distinction of individual senarmontite and digenite grains is not possible under the microscope and the two minerals may therefore form a submicroscopic intergrowth. Under crossed nicols a distinct twin- 
ning pattern characterizes the intergrowth, and it is also seen that intergrowth of the two secondary minerals forms pseudomorphs after rohaite grains.

An X-ray powder pattern obtained from an aggregate mounted in a Gandolfi camera shows the characteristic diffraction lines of both digenite and senarmontite.

A composite microprobe analysis of the secondary mineral aggregate in sample GGU 151102.1331 from which material for the X-ray crystallographic work was extracted gave: $\mathrm{Cu} 50.1 \%$, Sb $27.0 \%$, $\mathrm{Tl} 0.9 \%$, Fe $0.2 \%, \mathrm{~Pb} 0.1 \%$ and $\mathrm{S} 13.1 \%$ giving a total of $91.5 \%$. The presence of oxygen was proved by the microprobe but could not be determined quantitatively. The analysis suggests the following bulk composition of the analyzed material: $\mathrm{Sb}_{2} \mathrm{O}_{3} \cdot 3.86 \mathrm{Cu}_{1.93} \mathrm{~S}_{1.00}$. The small amounts of thallium, iron and lead may be contained in both of the secondary minerals. The low thallium contents show that the major part of the thallium of the rohaite was removed during alteration.

\section{Discussion}

Thallium minerals have so far only been found at two localities within the Ilímaussaq intrusion. Chalcothallite was discovered on the Taseq type locality (Semenov et al., 1967). Vrbaite (optically identified) occurs as a primary or secondary hypogene thallium-bearing mineral. It fills fractures in the chalcothallite. A secondary-supergene (?)alteration product is assumed to be avicennite. Small amounts of thallium are present in the cuprostibite from this locality (Sørensen et al., 1969). Rohaite was found at the Kvanefjeld cuprostibite locality associated with other sulphides, but none of these carried thallium in amounts detectable by the microprobe. Small amounts of thallium $(0.9 \%)$ were determined in the secondary intergrowth of digenite and senarmontite.

The formation of the thallium minerals is explained by the high content of thallium in agpaitic nepheline syenites as compared to that in the more common intrusive rocks. According to Gerasimovsky (1969) thallium contents range from $0.6 \mathrm{ppm}$ in the naujaites to $10.3 \mathrm{ppm}$ in the green lujavrites. This shows that the last-formed rock types are enriched in thallium. Presumably, further concentration of thallium in the late magmatic fluids have locally resulted in formation of thallium sulphides.

Both rohaite and chalcothallite are characterized by very low sulphur contents. This, combined with their pronounced micaceous habit, suggests a structure of alternating metal-metal and metal-sulphur layers. A structural determination of both chalcothallite and rohaite is currently in progress. The reason for crystallization of minerals with low sulphur contents, such as rohaite, is presumably the low sulphur fugacity which prevailed during the crystallization of the ore minerals at both localities (Karup-Møller, 1974, 1978). 
Chalcocite, digenite and associated secondary minerals from the Kvanefjeld cuprostibite locality

\section{Introduction}

Digenite, chalcocite, ?djurleite and associated supergene covellite, blaubleibender covellite (two varieties) and connellite have been found together with cuprostibite and other ore minerals in sample GGU 150102 from Kvanefjeld (fig. 1). The minerals digenite, blaubleibender covellite and ?djurleite are new for the Ilimaussaq massif.

\section{Mineral descriptions and relationships}

\section{Digenite and associated secondary chalcocite}

Digenite is isotropic to very weakly anisotropic under crossed nicols. The light blue reflectance colour of the mineral stands out against the grey-white colour of the associated chalcocite. The latter mineral shows weak to distinct anisotropism under crossed nicols. Both copper sulphides have been identified by their X-ray powder patterns.

Aggregates originally composed of high digenite alone have crystallized in contact with sphalerite and silicate minerals. The maximum size of the aggregates is half a centimetre. They are always subdivided into numerous segments by an irregular pseudo-rectangular fracture pattern. The fractures are filled with connellite considered to be supergene (see later). Each segment is composed of a lamellar intergrowth of low digenite and chalcocite (Plate 6 a). The proportion between the two minerals vary from one segment to another. They may represent the decomposition product of a high digenite with a composition between chalcocite $\left(\sim \mathrm{Cu}_{2} \mathrm{~S}\right)$ and low digenite $\left(\sim \mathrm{Cu}_{1.76} \mathrm{~S}\right)$. The fractures may have developed simultaneously with this decomposition process.

\section{Primary chalcocite}

Chalcocite occurs as a primary mineral interstitial to silicate minerals, sometimes in association with cuprite (Plate $6 \mathrm{~d}$ ). The mineral has also crystallized together with cuprostibite, sphalerite, rohaite and antimonian silver.

\section{Blaubleibender covellite}

Blaubleibender covellite has formed by alteration of digenite. It forms patchy replacement flakes, which extend from the connellite filled fractures into the digenite (Plate $6 \mathrm{~b}$ ). Sometimes digenite grains have been completely altered into an 
intergrowth of covellite and blaubleibender covellite. Two varieties of blaubleibender covellite with different optical properties and chemical composition have been identified.

One variety has a deep blue colour and no visible pleochroic effects. Under crossed nicols the grains display strong polarization colours. The composition of three grains in sample GGU $150102 \mathrm{c}$ is $\mathrm{Cu}_{1.42 \pm 0.02} \mathrm{~S}$. One of the analyzed grains is shown in plate $6 \mathrm{~b}$.

The second variety is characterized by a stronger dark blue colour, distinct reflectance pleochroism, strong anisotropism under crossed nicols and vivid polarization colours. Microprobe analyses on 7 grains in sample GGU 150102a gave $\mathrm{Cu}_{1.13 \pm 0.03}=\mathrm{S}$.

Frenzel (1959) originally considered the composition of blaubleibender covellite to lie close to $\mathrm{Cu}_{1.17} \mathrm{~S}$ but later he found varieties with compositions close to $\mathrm{Cu}_{1.40} \mathrm{~S}$ (Frenzel, 1961). Stillitoe \& Clark (1969) and Globe \& Smith (1973) have described two varieties of the mineral with compositions $\mathrm{Cu}_{1.12 \pm 0.03} \mathrm{~S}$ and $\mathrm{Cu}_{1.32 \pm 0.04} \mathrm{~S}$ respectively. Moh (1971) has identified two structurally different varieties of blaubleibender covellite, type $\mathrm{A}$ and type $\mathrm{B}$. Type $\mathrm{A}\left(\mathrm{Cu}_{1+\mathrm{x}} \mathrm{S}\right)$ belongs to the pure $\mathrm{Cu}-\mathrm{S}$ system and has a narrow compositional range. Type $\mathrm{B}$ contains trace elements, probably $\mathrm{O}$ and possibly also $\mathrm{OH}$. It has a compositional range from at least 66.5 to 74.0 per cent $\mathrm{Cu}\left(\sim \mathrm{CuS}\right.$ to $\left.\mathrm{Cu}_{1.43} \mathrm{~S}\right)$ based on the composition of naturally occurring varieties. Type $\mathrm{B}$ is a common supergene alteration product after primary copper sulphides. The two Ilímaussaq varieties may represent preferred compositions of type B.

\section{Covellite}

Intense alteration of digenite-chalcocite aggregates has resulted in the formation of covellite often accompanied by blaubleibender covellite.

\section{(?) Djurleite}

In sample GGU $150102 \mathrm{c}$ very rare exsolution lamellae of an unidentified mineral have been observed in low digenite - chalcocite aggregates (Plate $6 \mathrm{c}$ ). The mineral relationships displayed in the photograph suggest that the lamellae have exsolved before the decomposition of the original high digenite.

The colour of the mineral is slightly whiter than the associated chalcocite. Compared to chalcocite the reflectivity is distinctly higher and the anisotropism under crossed nicols stronger. The polishing hardness is higher than that of both chalcocite and digenite. Microprobe analyses of three lamellae gave rather similar results: $\mathrm{Cu}_{1.96} \mathrm{~S}$. This composition is very close to that of the rare mineral djurleite, which according to Roseboom (1966) is $\mathrm{Cu}_{1.96-1.97} \mathrm{~S}$. Uytenbogaardt \& Burke (1971, p. $60)$ stress that the optical properties of djurleite and chalcocite are very similar. The identity of the exsolution lamellae as djurleite has yet to be confirmed. 


\section{Cuprostibite alteration minerals}

\section{Introduction}

Alteration of cuprostibite from the Kangerdluarssuk and Kvanefjeld localities (fig. 1), has resulted in the formation of Sb-malachite (possibly a submicroscopic intergrowth of two or more phases), cuprite (several varieties), native copper, senarmontite and an unidentified mineral associated with the senarmontite. The mineralogical examinations have been completed on material from the Kangerdluarssuk cuprostibite locality unless otherwise stated.

\section{Mineral descriptions}

\section{Sb-malachite}

A characteristic green malachite like decomposition product of cuprostibite is present in all mineralized samples. The true identity of this substance is in doubt. An X-ray diffractometer diagram gave rather weak malachite diffraction lines whereas no results were obtained by the Guinier method. The mineral is thus poorly crystalline. This feature and the high content of antimony indicated by the microprobe may suggest a submicroscopic mixture of malachite and a non-crystalline Sb-rich unidentified phase. Alternatively, the antimony might be contained in the malachite structure.

Microprobe analyses of the Sb-malachite replacement aggregates (Table 8) show that the mineral contains more antimony than copper. The composition varies

Table 8. Microprobe analyses on $\mathrm{Sb}$-malachite

\begin{tabular}{|c|c|c|c|c|}
\hline & 1 & 2 & 3 & 4 \\
\hline $\mathrm{Sb} \ldots \ldots \ldots \ldots \ldots \ldots \ldots$ & 34.5 & 43.9 & 40.9 & 47.4 \\
\hline $\mathrm{Cu}$. & 27.8 & 16.5 & 22.2 & 16.2 \\
\hline O calc. $\ldots \ldots \ldots \ldots \ldots \ldots$ & 34.6 & 32.1 & 32.3 & 32.0 \\
\hline $\mathrm{C}$ calc. $\ldots \ldots \ldots \ldots \ldots \ldots$ & 5.1 & 4.8 & 5.1 & 5.0 \\
\hline \multirow[t]{2}{*}{$\mathrm{H}$ calc. $\ldots \ldots \ldots \ldots \ldots$} & 0.9 & 0.8 & 0.9 & 0.8 \\
\hline & $\overline{102.9}$ & $\overline{98.1}$ & $\overline{101.4}$ & $\overline{101.4}$ \\
\hline \multicolumn{5}{|l|}{ Atom ratio } \\
\hline$\ldots \ldots \ldots \ldots$ & 0.65 & 1.39 & 0.97 & 1.53 \\
\hline
\end{tabular}

1 and 2: banded Sb-malachite in sample GGU 151530.2

3 and 4: Sb-malachite in sample 151530.3

Standards were $\mathrm{Cu}$ and $\mathrm{Sb}$ 
Fig. 9. Microprobe scanning profile across banded $\mathrm{Sb}$-malachite aggregate showing variations in the antimony and copper contents. Sample GGU 151530.2 .

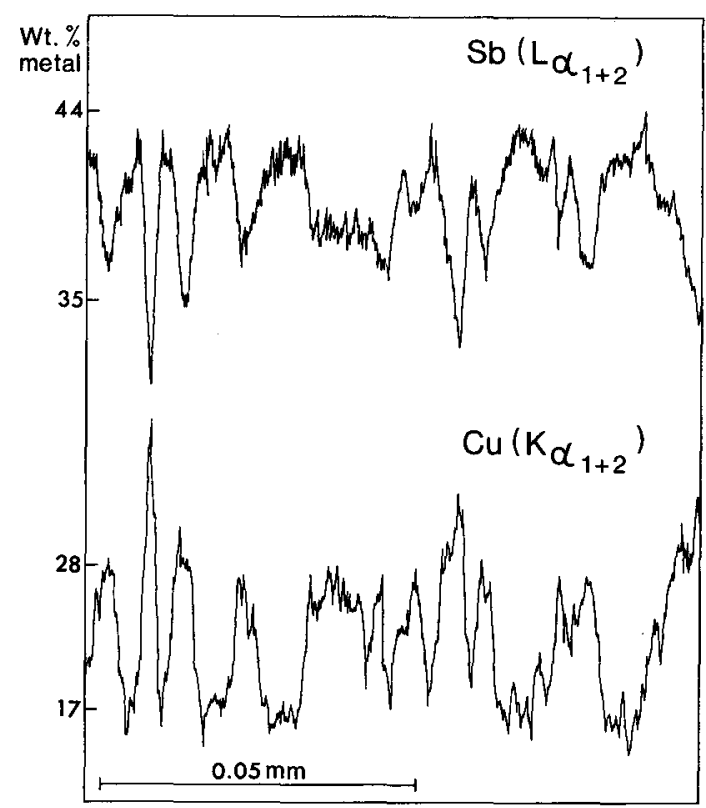

significantly from one aggregate to the next. The aggregates often show distinct concentric banding (Plate 7 a). In some cases the copper to antimony ratio varies significantly from one band to the next, in other cases no difference can be detected. A microprobe scanning profile across a banded Sb-malachite aggregate is shown in fig. 9. Quantitative analyses of a copper-rich and an antimony-rich band are listed in Table 8.

The variable composition across layered aggregates suggests (as assumed above) that these are composed of at least two chemically distinct phases present in different proportions.

The ZAF corrections of the microprobe data were carried out assuming a content of five per cent carbon in addition to oxygen but ignoring the presence of hydrogen. This assumption can only have caused little error because of the low atomic number of hydrogen. The amounts of oxygen, carbon and hydrogen which correspond stoichiometrically to the experimentally determined and corrected metal values, assuming a valency of +2 for copper and +3 for antimony, are listed in Table 8.

\section{Cuprite}

Cuprostibite always contains distinct alteration aggregates consisting of intergrowths of cuprite and darker unidentified mineral phases. There are both gradual and stepwise changes in chemical compositions and optical properties between 
these phases (Plate $7 \mathrm{~b}, \mathrm{c}$ ). X-ray crystallographic examination of the darker phases could not be carried out due to the small amount of material available. Microprobe analyses indicate, as discussed below, that the darkest varieties contain the highest amount of $\mathrm{OH}$ and/or $\mathrm{H}_{2} \mathrm{O}$. Gel textures are sometimes seen (Plate $7 \mathrm{~d}$ ). The darker phases may therefore represent 'hydrated cuprites' or 'gel-cuprites'. They are all referred to as cuprite in what follows.

Light grey reflecting cuprite, present as fracture fillings or developed in rather homogeneous areas with only small amounts of the darker varieties present, has weak to distinct anisotropism under crossed nicols. Red internal reflections are generally abundant. These properties correspond to those for cuprite given by Ramdohr (1975).

Light grey reflecting cuprite associated with significant amounts of darker grey varieties (Plate $7 \mathrm{~b}, \mathrm{c}$ ) is distinct to strongly anisotropic under crossed nicols and is without red internal reflections. An X-ray powder pattern of material from the aggregate shown in Plate $7 \mathrm{c}$ gave cuprite diffraction lines. The grain size of the mineral is less than $0.02 \mathrm{~mm}$. The darker coloured varieties also show pronounced anisotropism under crossed nicols, and they also lack the red internal reflections.

Microprobe analyses were carried out on light and dark cuprite varieties of the type without red internal reflections. In sample GGU 151530.2, an aggregate characterized by a heterogeneous, sometimes banded mixture of light and dark cuprite was investigated (Plate $7 \mathrm{c}$ ). Microprobe analyses on light, medium and dark reflecting cuprite are listed in Table 9 . The antimony content varies significantly. The small amount of silicon present apparently is independent of the antimony content.

In sample GGU 151530.151-c cuprostibite contains several patchy cuprite areas similar to those shown in Plate $7 \mathrm{~b}$. Analyses on light grey to almost black cuprite varieties are listed in Table 9, column 4-7. In addition to antimony and silicon

Table 9. Microprobe analyses on cuprite

\begin{tabular}{|c|c|c|c|c|c|c|c|}
\hline & 1 & 2 & 3 & 4 & 5 & 6 & 7 \\
\hline $\mathrm{Cu}$ & 87.5 & 77.6 & 71.1 & 80.3 & 66.1 & 45.9 & 28.5 \\
\hline $\mathrm{Pb} \ldots \ldots \ldots \ldots \ldots \ldots$ & - & - & - & 1.1 & 9.5 & 17.5 & 24.3 \\
\hline $\mathrm{Sb} \ldots \ldots \ldots \ldots \ldots \ldots$ & 1.6 & 2.7 & 8.4 & 1.3 & 2.9 & 3.3 & 3.9 \\
\hline $\mathrm{Si} \ldots \ldots \ldots \ldots \ldots \ldots$ & 0.3 & 0.7 & 0.5 & 0.2 & 0.8 & 1.6 & 3.8 \\
\hline \multirow[t]{2}{*}{$\mathrm{o}$ calc. .............. } & 11.7 & 11.1 & 10.4 & 10.7 & 10.5 & 9.6 & 10.6 \\
\hline & 100.4 & 92.1 & 90.4 & 93.6 & 89.7 & 78.9 & 71.1 \\
\hline
\end{tabular}

1-3: cuprite in sample GGU 151530.2, light medium and dark reflecting varieties respectively 4-7: cuprite in sample $151530.151-c$, grey-white to almost black varieties Standards were $\mathrm{Cu}, \mathrm{Sb}, \mathrm{PbS}$ and $\mathrm{SiO}_{2}$ 
surprisingly large amounts of lead were recorded. This metal is considered to have been derived from alteration of galena enclosed in cuprostibite at a few millimetres distance from the cuprite areas. Lead in the cuprostibite could not be detected by the microprobe.

The ZAF corrections of the microprobe data were carried out assuming the presence of a pure oxide, ignoring the possible content of hydrogen in the mineral. The amount of oxygen equivalent to all the elements in each of the eight analyses listed in Table 9 has been calculated assuming a valency of +1 for copper, +2 for lead, +3 for antimony and +4 for silicon. The discrepancy of the sum of metal and calculated oxygen values from one hundred per cent increases with decreasing copper content and increasing content of the other elements. Only one explanation appears acceptable. Increasing contents of $\mathrm{OH}^{-}$and $\mathrm{H}_{2} \mathrm{O}$ in the mineral accompany increasing contents of lead, antimony and silicon. The easier destruction of the low reflecting phases than of the light grey reflecting phase under the electron beam supports this conclusion.

\section{Senarmontite and the associated unidentified mineral}

One of the major cuprostibite alteration products consists of a light grey mixture of very fine-grained senarmontite and an unidentified mineral. Both have nearly similar optical properties. The unidentified mineral is platy to fibrous in shape. Guinier powder examination of material from the Kangerdluarssuk and the Kvanefjeld localities gave similar results. In addition to senarmontite lines several unidentified lines are attributed to the unidentified mineral. In Guinier film 1619 of material from the Kvanefjeld locality (sample GGU 150102c) the $\mathrm{d}_{\mathrm{hkl}}$ values and the visually estimated intensity of these lines are 9.59(3), 3.173(8), 3.087(5), $2.962(10), 2.451(5), 2.070(4), 1.949(5), 1.757(3), 1.648(2)$ and 1.62(2).

In sample $150102 \mathrm{c}$ the grain size of the two minerals was sufficiently large to permit microprobe analyses (Table 10).

Table 10. Microprobe analyses on senarmonite and associated unidentified mineral

\begin{tabular}{lcccc} 
& \multicolumn{2}{c}{$\begin{array}{c}\text { Senarmontite } \\
\text { Wt. \% }\end{array}$} & \multicolumn{2}{c}{ Unidentified mineral } \\
& Atom ratio & Wt. \% & Atom ratio \\
\hline $\mathrm{Sb} \ldots \ldots \ldots \ldots \ldots \ldots \ldots$ & $76.2 \pm 1.2$ & 1.84 & $58.5 \pm 1.9$ & $2.92\}$ \\
$\mathrm{Cu} \ldots \ldots \ldots \ldots \ldots \ldots$ & $5.0 \pm 0.5$ & 0.23 & $11.3 \pm 1.6$ & $1.08\} 4.00$ \\
$\mathrm{O}$ calc. $\ldots \ldots \ldots \ldots \ldots \ldots$ & 16.3 & 3.00 & 23.1 & 10.92 \\
$\mathrm{H}$ calc. $\ldots \ldots \ldots \ldots \ldots$ & $\frac{-}{97.5}$ & & 5.7 & 10.92 \\
& & & \\
\hline
\end{tabular}

Sample GGU 150102c. Standards were $\mathrm{Cu}$ and $\mathrm{Sb}$ 
The copper to antimony ratio in the senarmontite is $1: 8.09$.

The copper to antimony ratio in the unidentified mineral is $1: 2.7$. The microprobe analyses show that the mineral is not a pure oxide but is likely to contain either $\mathrm{OH}^{-}$or $\mathrm{H}_{2} \mathrm{O}$ or both. This assumption is substantiated by the easy destruction of the polished surface when exposed to the electron beam. A similar destruction of the senarmontite surface does not take place. The ZAF corrections were completed assuming a pure hydroxide, yielding the formula $\mathrm{Cu}_{1.08} \mathrm{Sb}_{2.92}(\mathrm{OH})_{10.92}$ or idealized $\mathrm{Cu}_{1} \mathrm{Sb}_{3}(\mathrm{OH})_{11}$. The only copper-antimony mineral of this nature known to the author is partzite $\left(\mathrm{Cu}_{y} \mathrm{Sb}_{2-x}\left(\mathrm{O}, \mathrm{OH}, \mathrm{H}_{2} \mathrm{O}\right)_{6-7}, y=\max .2\right.$ and $x=\max .0 .1$, Mason \& Vitaliano, 1953). However, the diffraction lines of partzite are different from those of the unidentified mineral listed above.

\section{Native copper}

One microprobe analysis on native copper gave an antimony content of 0.7 per cent.

\section{Mineral relationships}

Senarmontite and an associated unidentified mineral have developed by alteration of cuprostibite. Part of the copper released crystallized as light grey (antimony-free) cuprite replacing silicate minerals, mainly aegirine and analcime, or filling fractures in these (Plate $7 \mathrm{e}$ ). Cuprite also crystallized as patchy aggregates replacing cuprostibite. Some of these patches are composed only of the light grey reflecting antimony-free cuprite, others consist of an intergrowth of differently reflecting varieties of cuprite (Plates $7 \mathrm{~b}$, c). Rarely gel textures are developed within these aggregates (Plate $7 \mathrm{~d}$ ). Native copper associated with minor cuprite occurs as fracture fillings in cuprostibite. The native copper does not extend into adjacent silicate minerals (Plate $7 \mathrm{f}$ ). Part of the exposed mineral veins at localities 2 and 3 in fig. 1 is stained by Sb-malachite. In polished sections Sb-malachite is seen to form replacement aggregates up to a few millimetres in size in cuprostibite. The mineral also occurs associated with minor amounts of cuprite along fracture veinlets cutting cuprostibite and silicate minerals. Extensively altered cuprostibite may consist of a mixture of all four alteration minerals in greatly varying proportions.

\section{Conditions of formation}

The Sb-malachite staining shows that alteration of cuprostibite is supergene, post-glacial in age and should therefore still be active at the present time. Primary carbonate minerals are extremely rare within the Ilimaussaq alkaline intrusion (Sørensen, 1962; Sørensen et al., 1970). They have not been found at the two cuprostibite localities. $\mathrm{CO}_{2}$ tied up in the relatively abundant Sb-malachite is there- 
fore considered to have been derived from the atmosphere and dissolved in the percolating rain waters, causing the alteration processes. The stability conditions of $\mathrm{Sb}$-malachite, cuprite and native copper in the system $\mathrm{Cu}-\mathrm{H}_{2} \mathrm{O}-\mathrm{O}_{2}-\mathrm{S}-\mathrm{CO}_{2}$ at a temperature of $25^{\circ} \mathrm{C}$ and a pressure of one atmosphere have been indicated by Garrels \& Christ (1965, p. 240). The effect of the addition of antimony to the mineral stability field is not known. Assuming that these changes are small, then the stability conditions of Sb-malachite, cuprite and native copper suggest that the supergene solutions were slightly acid $(\mathrm{pH} \sim 4-7)$ with a low positive oxidation potential $(\mathrm{Eh} \sim 0.0 \pm 0.30)$.

The occurrence of connellite, brochantite, linarite and senarmontite

\section{Introduction}

At the cuprostibite locality on the Kvanefjeld plateau (fig. 1) fractures in digenite are filled with connellite. At the locality at Kangerdluarssuk rare cavities less than one centimetre in size are filled with one or several of the following minerals: connellite, linarite, brochantite, senarmontite and Sb-malachite or azurite.

\section{Mineral descriptions}

\section{Connellite}

At the Kvanefjeld cuprostibite locality digenite-chalcocite aggregates with a maximum size of half a centimetre are enclosed in silicate minerals (sample GGU 150102). The aggregates show a pseudo-rectangular fracture pattern filled with connellite. The formation of connellite was accompanied by the partial alteration of digenite and chalcocite to blaubleibender covellite and covellite. Guinier powder examination of a mixture of digenite and connellite has confirmed the identity of both minerals (film no. 2028). A composite microprobe analysis representing several connellite grains in sample GGU 150102.1331 gave: $\mathrm{CuO} 68.0 \%, \mathrm{Sb}_{2} \mathrm{O}_{3}$ $1.5 \%, \mathrm{ZnO} 1.0 \%, \mathrm{Cl} 7.0 \%, \mathrm{SO}_{3} 3.7 \%$. (ARL microprobe model EMX. Standards used were: $\mathrm{Sb}, \mathrm{Cu}, \mathrm{Zn}, \mathrm{PbS}$, and $\mathrm{NaCl}$ ). Compositions of connellite from four localities listed by McLean \& Anthony (1972) lie within the following ranges: $\mathrm{CuO}$ $73.11-73.96 \%, \mathrm{SO}_{3} 3.15-3.98 \%, \mathrm{~N}_{2} \mathrm{O}_{5} 0-0.72 \%, \mathrm{Cl} 6.82-7.09 \%$ and $\mathrm{H}_{2} \mathrm{O}$ $16.75-17.55 \%$.

At the Kangerdluarssuk cuprostibite locality cavities in sample GGU 151337 contain connellite associated with an extremely fine-grained unidentified mineral. Connellite generally forms slender prisms, hardly exceeding a few tenths of a millimetre in length (Plate 8 a). Short stumpy crystals are rare (Plate 8 b). Sometimes the prism faces appear to be slightly curved; but these curved faces may 
actually be due to a combination intergrowth of prism and pyramide faces (Plate 8 c). The crystals often terminate in what appears to be a very steep pyramid (Plate 8 d).

The cell dimensions of connellite from the Kangerdluarssuk locality (refined on basis of Guinier powder data (film no. 1949) and using the REFBASE III program written by E. Leonardsen, Institute of Mineralogy, University of Copenhagen) are a $15.751 \pm 0.003 \AA$ and $c 9.122 \pm 0.003 \AA$.

\section{Brochantite}

A few cavities in sample GGU 151337 are filled with a dark olive-greenish-grey, very fine-grained, compact aggregate of brochantite. Guinier powder examination (film no. 1977) gave only brochantite lines, identical to those listed on ASTM card 13-398. Calculated cell dimensions are $a 12.773 \pm 0.009 \AA, b 9.862 \pm 0.008 \AA$ and c $6.015 \pm 0.005 \AA$.

Chemical determinations on the mineral by N. Hansen, Institute of Mineralogy, University of Copenhagen, gave a copper content of only 39.2 per cent. However, the investigation indicated the presence of substantial amounts of antimony. The samples for the chemical analysis and the Guinier powder examination were taken from the same specimen and are considered representative for the same mineral. Only brochantite diffraction lines were identifid in the Guinier powder pattern. Unless a non-crystalline antimony-rich phase is present, it may be assumed that substantial amounts of antimony are contained in the brochantite.

\section{Linarite}

Prismatic crystals of linarite with a maximum length of $0.1 \mathrm{~mm}$ have been found in one cavity, half a centimetre in size, in sample GGU 151337. The mineral cannot be distinguished macroscopically from connellite due to the similar light blue colour, habit and crystal size. The cell dimensions of the investigated linarite (refined on basis of Guinier powder film 2191) deviate slightly from those of the linarite

Table 11. Cell dimensions of linarite

\begin{tabular}{|c|c|c|}
\hline $\begin{array}{c}\text { Ilímaussaq } \\
\text { (GGU 151337) }\end{array}$ & Berry (1951) & $\begin{array}{c}\text { Bachmann } \\
\text { \& Zemann (1961) }\end{array}$ \\
\hline$a=9.712 \AA \pm 0.005 \AA \ldots$ & $9.70 \AA$ & $9.81 \AA$ \\
\hline$b=5.657 \AA \pm 0.003 \AA \ldots$ & $5.65 \AA$ & $5.65 \AA$ \\
\hline$c=4.659 \AA \pm 0.002 \AA$. & $4.68 \AA$ & $4.70 \AA$ \\
\hline$\beta \pm 102^{\circ} 32^{\prime} \pm 3^{\prime} \ldots$. & $102^{\circ} 40^{\prime}$ & $104^{\circ} 42^{\prime}$ \\
\hline
\end{tabular}


studied by Berry (1951), but differ substantially from those of the linarite described by Bachmann \& Zemann (1961) (Table 11).

An average microprobe analysis of several mineral grains gave, in addition to copper, lead and sulphur, a zinc content of 0.7 per cent.

\section{Senarmontite}

A one centimetre large cavity in sample GGU 151395 is filled with a porous aggregate of octahedra of senarmontite (Plate $8 \mathrm{e}$ ). In sample GGU 151396 smaller sized cavities are filled with similar senarmontite material. However, in some of the cavities the senarmontite is associated with connellite and also with a mineral, possibly malachite or azurite, shaped as platy crystals (Plate $8 \mathrm{f}$ ). This material could not be isolated for X-ray powder examination.

\section{Mode of formation}

The minerals connellite, brochantite, linarite and senarmontite are new for Greenland. These minerals are generally known to develop by supergene alteration of copper, lead and/or antimony-bearing sulphides. The mode of occurrence of the minerals at the two cuprostibite localities within the Ilimaussaq intrusion strongly suggests a similar origin. The metal content of the mineralizing solution was presumably derived essentially from the alteration of cuprostibite, digenite and galena. The chlorine of the connellite may originate from sodalite, which occurs as a very common mineral within the intrusion.

\section{Acknowledgements}

S.K.-M. wishes to express his appreciation for the interest of Professor H. Sørensen, Institute of Petrology, and Dr. E. Makovicky and cand.real. E. Leonardsen, Institute of Mineralogy, University of Copenhagen. The synthetic Ag-Sb standards used for the microprobe work were kindly obtained from Dr. D. C. Harris, Mines Branch, Ontario, Canada. The project was supported by grant nos. 511-1887 and 511-167-2/69 from the Danish Natural Science Research Council. 


\section{REFERENCES}

Bachmann, H. G. \& Zemann, J. 1961: Die Kristallstruktur von Linarit, $\mathrm{PbCuSO}_{4}(\mathrm{OH})_{2}$. Acta Cryst. 14, 747-753.

Berry, L. G. 1951: The unit cell of linarite. Amer. Miner. 36, 511-512.

Engell, J., Hansen, J., Jensen, M., Kunzendorf, H. \& Løvborg, L. 1971: Beryllium mineralization in the Ilimaussaq intrusion, South Greenland with desription of a field beryllometer and chemical methods. Rapp. Gronlands geol. Unders. 33, 40 pp.

Ferguson, J. 1964: Geology of the Ilimaussaq alkaline intrusion, South Greenland. Bull. Grønlands geol. Unders. 39 (also Meddr Grønland 172,4) 82 pp.

Frenzel, G. 1959: Idait und 'Blaubleibender Covellin'. Neues Jb. Miner. Abh. 93, 87-132.

Frenzel, G. 1961: Der Cu-Überschuss des blaubleibenden Covellins. Neues Jb. Miner. Mh. 9, $199-204$.

Garrels, R. M. \& Christ, C. L. 1965: Solutions, minerals and equilibria. New York. 450 pp.

Gerasimovsky, V. I. 1969: [Geochemistry of the Ilimaussaq alkaline massif.] Moscow: Nauka. 175 pp. (In Russian).

Globe, R. J. \& Smith, D. G. W. 1973: Electron microprobe investigation of copper sulphides in the Precambrian Lewis Series of S. W. Alberta, Canada. Can. Miner. 12, 95-103.

Hey, M. H. 1970: Twenty-sixth list of new mineral names. Mineralog. Mag. 37, 954-967.

Igelström, R. J. 1865: Nya och sällsynta mineralier från Värmland. Öfvers. K. svenska VetenskAkad. Förh. 22, 227-229.

Karup-Møller, S. 1974: Mineralogy of two copper-antimony-sulphide-oxide occurrences from the Ilímaussaq alkaline intrusion in South Greenland. Neues Jb. Miner. Abh. 122, 291-313.

Karup-Møller, S. 1978: The ore minerals of the Ilimaussaq intrusion: their mode of occurrence and their conditions of formation. Bull. Grønlands geol. Unders. 127.

Karup-Møller, S. \& Makovicky, E. 1974: Skinnerite, $\mathrm{Cu}_{3} \mathrm{SbS}_{3}$ - a new copper-antimony sulphosalt mineral. Amer. Miner. 59, 889-895.

Kogarko, L. N. 1974: Role of volatiles. In Sørensen, H. (edit.) The alkaline rocks. 474-487. London: Wiley.

Larsen, L. M. 1976: Clinopyroxenes and coexisting mafic minerals from the alkaline Ilimaussaq intrusion, South Greenland. J. Petrol. 17, 258-290.

López-Soler, A., Bosch-Figueroa, J. M., Karup-Møller, S., Besteiro, J. \& Font-Altaba, M. 1975: Optical study of cuprostibite $\left(\mathrm{Cu}_{2} \mathrm{Sb}\right)$. Fortsch. Miner. 52, 557-565.

Mason, B. \& Vitaliano, C. J. 1953: The mineralogy of antimony oxides and antimonates. Mineralog. Mag. 30, 100-112.

McLean, W. J. \& Anthony, J. W. 1972: The disordered, 'zeolite-like' structure of connellite. Amer. Miner. 57, 426-438.

Moh, G. H. 1971: Blue remaining covellite and its relations to phases in the sulphur rich portion of the copper-sulphur system at low temperatures. Spec. Pap. Mineralog. Soc. Japan. 1, 226-231.

Peacock, M. A. 1940: On dyscrasite and antimonial silver. Univ. Toronto Stud. Geol. Ser. 44, 31-46.

Petersilie, I. A. \& Sørensen, H. 1970: Hydrocarbon gases and bituminous substances in rocks from the Ilimaussaq alkaline intrusion, South Greenland. Lithos 3, 59-76.

Petruk, W., Cabri, L. J., Harris, D. C., Stewart, J. M., \& Clark, L. A. 1970: Allargentum, redefined. Can. Miner. 10, 163-172.

Petruk, W., Harris, D. C., Cabri, L. J. \& Stewart, J. M. 1971: Characteristics of the silver-antimony minerals. Can. Miner. 11, 187-195.

Piotrowski, J. M. \& Edgar, A. D. 1970: Melting relations of undersaturated alkaline rocks from South Greenland. Meddr Grønland 181,9,62 pp.

Ramdohr, P. 1975: The ore minerals and their intergrowth. 3rd ed. Pergamon Press. 1174 pp.

Roseboom, E. H. 1966: An investigation of the system Cu-S. Econ. Geol. 61, 641-671. 
Semenov, E. I., Sørensen, H., Bezsmertnaya, M. S. \& Novorossova, L. E. 1967: Chalcothallite - a new sulphide of copper and thallium from the Ilimaussaq alkaline intrusion, South Greenland. Bull. Grønlands geol. Unders. 68 (also Meddr Grønland 181,5) 13-26.

Skinner, B. J., Luce, F. D. \& Makovicky, E. 1972: Studies of the sulfosalts of copper III. Phases and phase relations in the system Cu-Sb-S. Econ. Geol. 67, 924-938.

Somanchi, S. 1966: Subsolidus phase relations in the system Ag-Sb. Can. J. Earth Sci. 3, 211-272.

Sørensen, H. 1962: On the occurrence of steenstrupine in the Ilimaussaq Massif, Southwest Greenland. Bull. Grønlands geol. Unders. 32 (also Meddr Grønland 167, 1) 251pp.

Sørensen, H. 1969: Rhythmic igneous layering in peralkaline intrusions. Lithos 2, 261-283.

Sørensen, H., Leonardsen, E. S. \& Petersen, O. V. 1970: Trona and thermonatrite from the Ilímaussaq alkaline intrusion, South Greenland. Bull. geol. Soc. Denmark 20, 1-19.

Sørensen, H., Rose-Hansen, J., Nielsen, B. L., Løvborg, L., Sørensen, E. \& Lundgaard, T. 1974: The uranium deposit at Kvanefjeld, the Ilimaussaq intrusion, South Greenland. Rapp. Grønlands geol. Unders. 60, $54 \mathrm{pp}$.

Sørensen, H., Semenov, E. I., Bezsmertnaya, M. S. \& Khalezova, E. B. 1969: [Cuprostibite - a new natural compound of copper and antimony.] Zap. Vses. Miner. Obshch. (2), 98,6, 716-724. (In Russian).

Springer, G. 1967: Die Berechnung von Korrekturen für die quantitative Elektronenstrahl-Mikroanalyse. Fortsch. Miner. 45, 103-124.

Stillitoe, R. H. \& Clark, A. H. 1969: Copper and copper-iron sulphides as the initial products of supergene oxidation, Copiapo mining district, northern Chile. Amer. Miner. 54, 1684-1710.

Strunz, H. 1970: Mineralogische Tabellen. Leipzig: Akademischer Verlag. 621 pp.

Uytenbogaardt, W. \& Burke, E. A. J. 1971: Tables for microscopic identification of ore minerals. Amsterdam: Elsevier. $430 \mathrm{pp}$. 


\section{Plate 1}

a. Subhedral crystals of partly altered cuprostibite enclosed in chalcocite. A light grey alteration rim of cuprite defines the original crystal outlines. The dark phase is senarmonite. $(\times 225$. Oil immersion. Sample GGU 150102a).

b. Two subhedral loellingite crystals enclosed in cuprostibite are separated by silver $(1) .(\times 300$. Oil immersion. Sample GGU 150102c).

c. Silver(1) (bright white) in contact with cuprostibite (medium grey area in the very left part of the photograph) occurs as host for small loellingite crystals (light grey), chalcocite (dark grey), rohaite (very dark grey) and aegirine (black). (× 530. Oil immersion. Sample GGU 150102b).

d. Grain of silver(1) enclosed in sphalerite cut by thin irregular chalcocite veinlets. Anhedral crystals of cuprite (dark grey) and cuprostibite (light grey) are enclosed in the silver(1). Two cuprostibite grains in the upper left and right part of the photograph are partly intergrown with cuprite. $(\times 530$. Oil immersion. Sample GGU 150102a).

e. Grain of silver(1) in graphic intergrowth with cuprostibite (grey), valentinite and cuprite (black). ( $\times$ 810. Oil immersion. Sample GGU 150102e).

f. Aggregate of silver(1) (white, 3.8) and silver(2) (grey, 3.11). The latter contains exsolved lamellae of silver(1) (white lamellae, 3.9) and lamellae of allargentum (dark grey, 3.10). The numbers, e.g. 3.8, refer to analysis 8 in Table 3 . Selective partial alteration of the allargentum lamellae has resulted in the formation of secondary silver(3) with numerous inclusions of very fine grained cuprite and senarmontite ( $\times$ 580. Oil immersion. Sample GGU 150102g).

g. Silver(2) with exsolved lamellae of allargentum (dark grey) and silver(1) (white). $(\times 525$. Oil immersion. Sample GGU 150102g). 

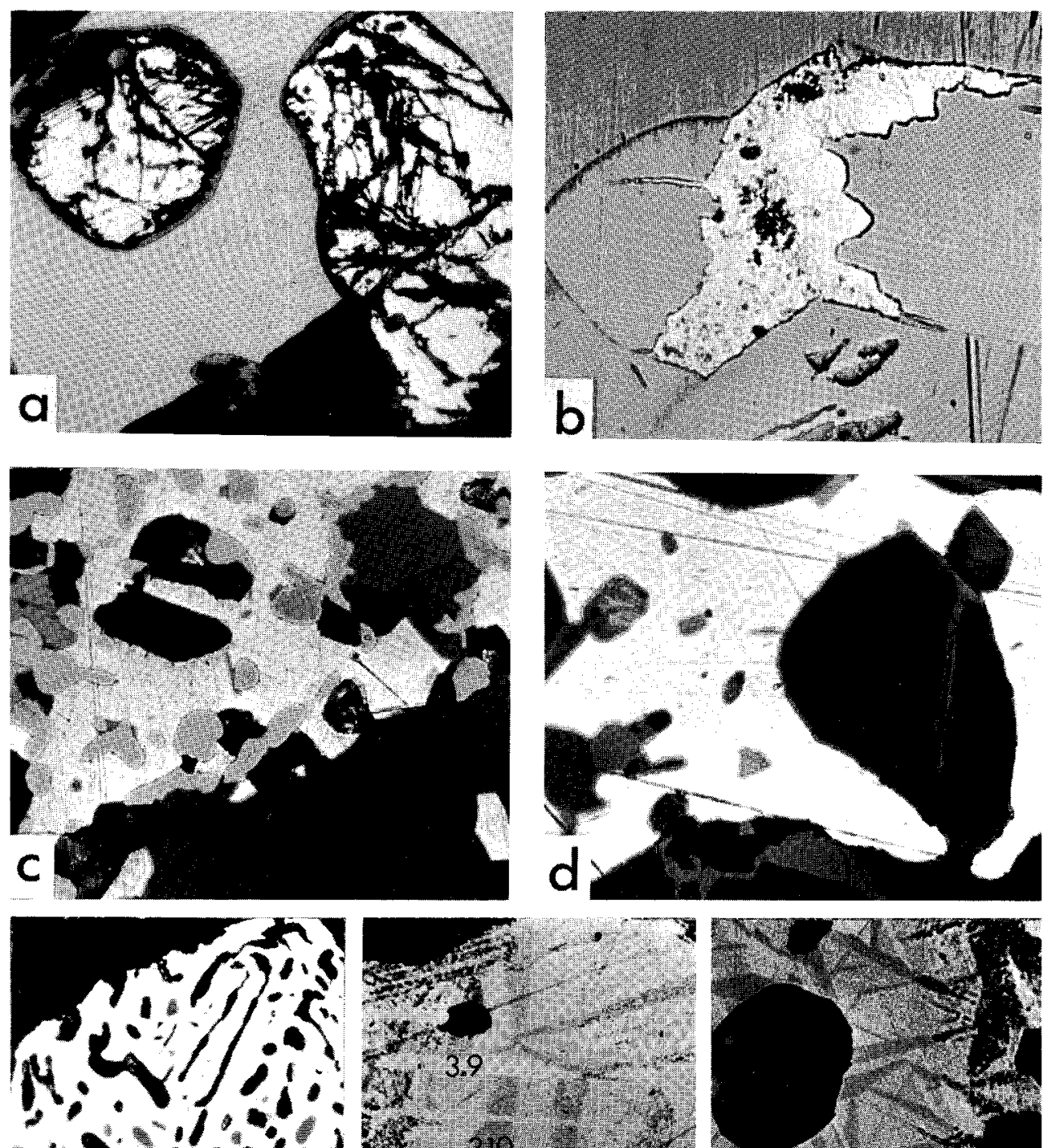

B.x. 3.9

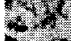

(1)

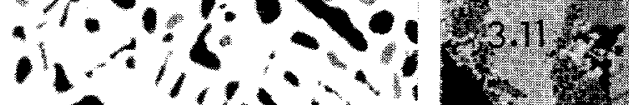

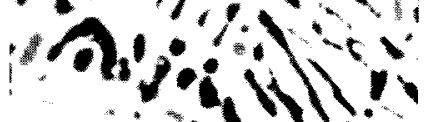

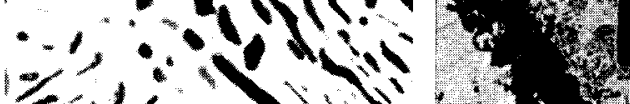

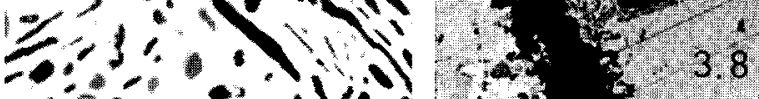

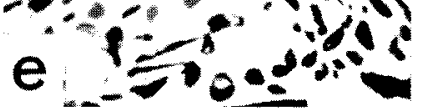
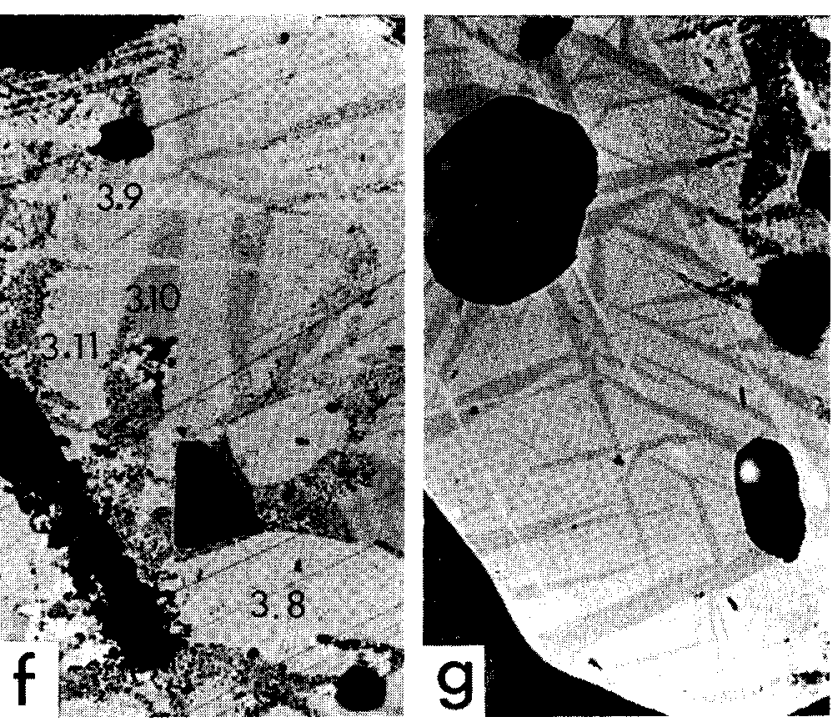


\section{Plate 2}

a. Dyscrasite (grey) contains a few irregularly shaped grains of native copper (same shade and brightness as dyscrasite). The margins of the native copper grains are altered to cuprite (black). Part of the dyscrasite is altered to antimonian silver (white) disseminated with very fine-grained cuprite (black). $(\times$ 420. Oil immersion. Sample GGU 151530.3).

b. Dyscrasite (grey) contains very irregularly shaped allargentum (light grey). The central part of the antimonian silver grain (bright white) in the middle part of the photograph contains very fine-grained senarmontite. Similar senarmontite occurs at random in the antimonian silver at the bottom left. Irregularly shaped mineral A grains (black) occur at random in the dyscrasite. The black area at the bottom left is analcime. The oval shaped galena grain (light grey) at the bottom has been partially replaced by digenite (dark grey), the major portion of which has been transformed into chalcocite (medium grey). The photographed area is located almost in the middle of fig. 7. $(\times 320$. Oil immersion. Sample GGU 151530.772-4).

c. Dyscrasite (1) has been altered into grains of antimonian silver disseminated with senarmontite and cuprite. The scarcity of oxide inclusions in the marginal areas of the antimonian silver grains marks the boundary between these. An irregularly shaped cuprite area at the upper right contains considerable amounts of native copper (2). A few circular to ovale shaped galena grains are now completely replaced by chalcocite. ( $\times 210$. Air. Sample GGU 151530.3).

d. Irregularly shaped inclusions of cuprite lie in antimonian silver disseminated with very finegrained cuprite. The cuprite inclusions crystallized in graphic intergrowth with dyscrasite but have survived the alteration of this mineral except for the transformation of the margins into a dark unidentified copper-antimony mineral. Two chalcocite pseudomorphs after galena similar to those shown in Plate $2 \mathrm{c}$ are also present $(\times 410$. Oil immersion. Sample GGU 151530.3). 

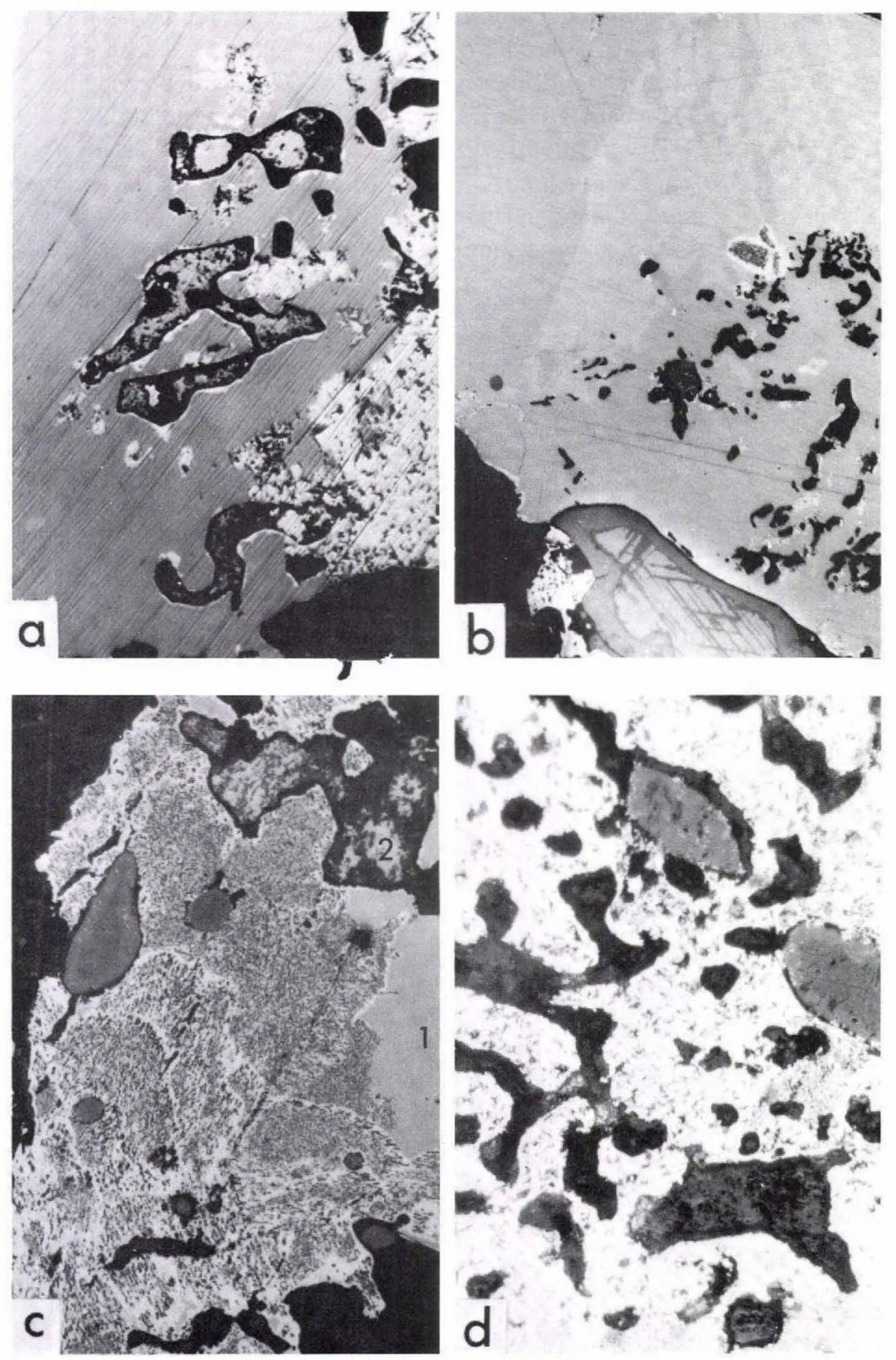


\section{Plate 3}

a. Galena, now completely replaced by homogeneous chalcocite with the very regularly formed fracture pattern marking the original galena cleavage directions, has crystallized in association with sphalerite (dark grey) along a fracture in analcime. The margin of the fracture is marked by white stippled lines. The original galena grain boundaries are preserved. The chalcocite rim without fractures around the sphalerite grains developed during replacement of the marginal areas of these grains, and its outer edge may therefore represent the original galena-sphalerite contact. Cuprite and antimonian silver are present along both sides of the chalcocite. ( $\times 35$. Oil immersion. Sample GGU 151530.2).

b. One relatively large and several small irregularly shaped grains of mineral A lie embedded in dyscrasite which is locally altered into antimonian silver with inclusions of senarmontite. The photographed area is located around the mineral A grain no. 6 in fig. 7. $(\times 300$. Oil immersion. Sample GGU $151530.772-4)$.

c. Dyscrasite along a fracture in aegirine containing numerous grains of mineral $\mathrm{A}$ in its central portion. The grains occur in graphic intergrowth with the dyscrasite host. A chalcocite pseudomorph after a corroded galena grain occurs in the dyscrasite at the bottom centre of the photograph. A few primary cuprite grains are also present (of same colour and brightness as chalcocite but smaller and without fractures). A minor part of the dyscrasite is altered into antimonian silver with inclusions of senarmontite. $(\times$ 320. Oil immersion. Sample GGU 151530.3).

d. Galena with an antimonian silver-disseminated chalcocite replacement rim occurs in antimonian silver with inclusions of senarmontite. $(\times 515$. Oil immersion. Sample GGU 151530.7).

e. Dyscrasite grain (grey) in cuprostibite (dark grey) has been partly altered to antimonian silver (white). Only a minor portion of the antimony tied up in the altered dyscrasite structure has been retained as senarmontite (black grains outside the stippled areas) while the major part has been removed. Copper derived from altered cuprostibite was enclosed in the antimonian silver. Here it crystallized as cuprite (black grains inside the stippled area) and as native copper interstitial to the antimonian silver grains. (The colour and brightness of the native copper is very similar to that of dyscrasite on the photograph). $(\times 420$. Oil immersion. Sample GGU 151530.2). 

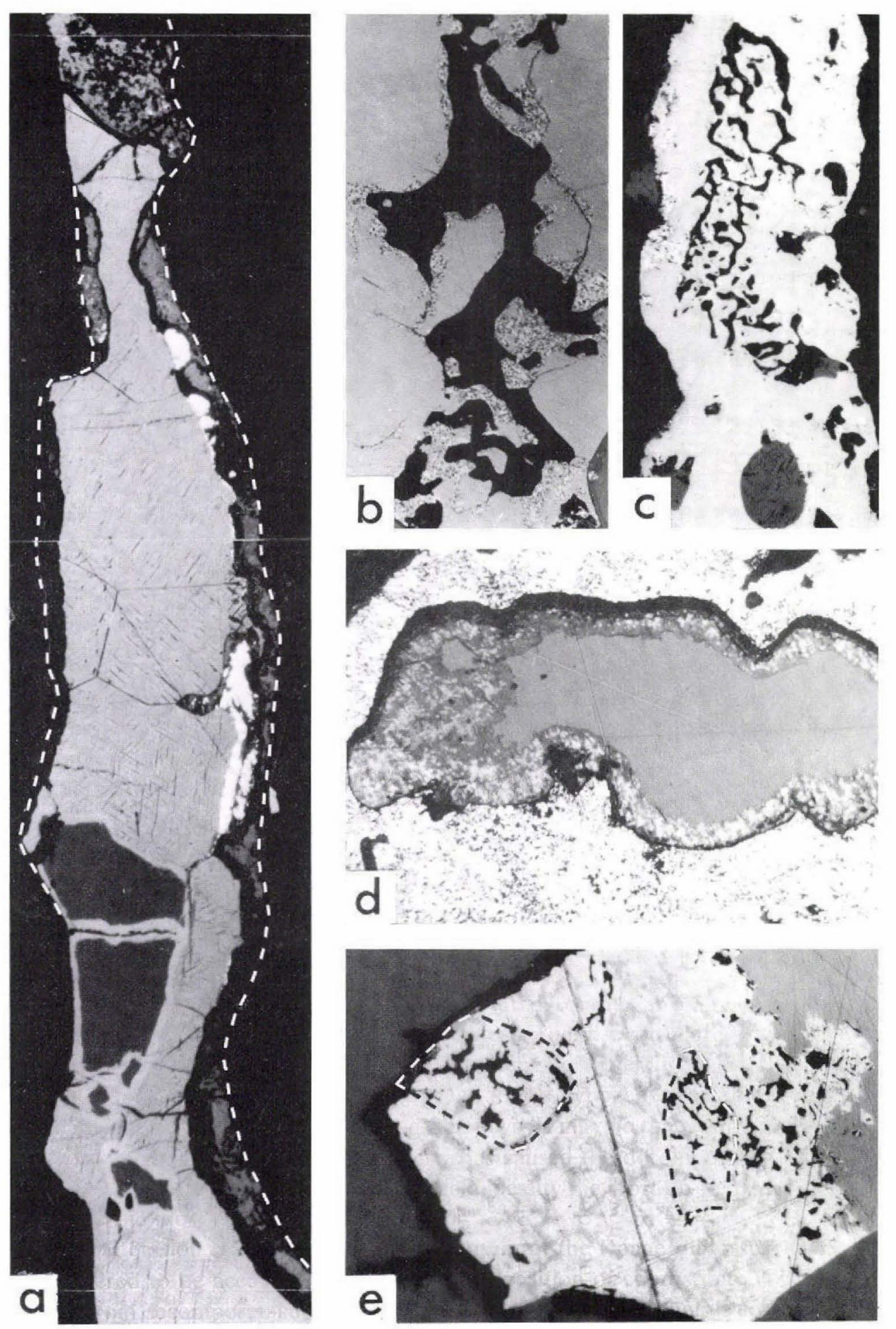


\section{Plate 4}

a. Mineral $\mathbf{A}$ and aegirine occur as host for aggregates of galena grains which are partly altered into digenite. Most of the digenite has been transformed into chalcocite with a few 'shrinkage' cracks. Chalcocite with a regular fracture pattern lying parallel to the galena cleavage directions has developed at the very right in the figure. Grains of antimonian silver are enclosed in mineral $\mathrm{A}$. The photographed area is located between 2 and 3 in fig. 7. ( $\times 230$. Oil immersion. Sample GGU 151530.772-4).

b. Enlargement of the area at the right side of Plate 4 a. Note that even the few short and randomly distributed cracks in the rather smooth rim of chalcocite all lie parallel to the galena cleavage directions. ( $\times$ 690. Oil immersion. Sample GGU 151530.772-4).

c. Galena in analcime has been almost completely replaced by digenite. The major portion of the digenite has crystallized to chalcocite with only a few cracks. $(\times 640$. Oil immersion. Sample GGU $151530.772-4)$.

d. Almost completely altered galena grains enclosed in analcime. Considerable amounts of an unidentified copper-antimony mineral occur along the margins of each altered galena grain. A band of the same mineral cuts across one of the altered grains, separating poorly recrystallized chalcocite with a few cracks from chalcocite with the pseudomorphic fracture pattern well developed. $(\times 620$. Oil immersion. Sample GGU 151530.2). 


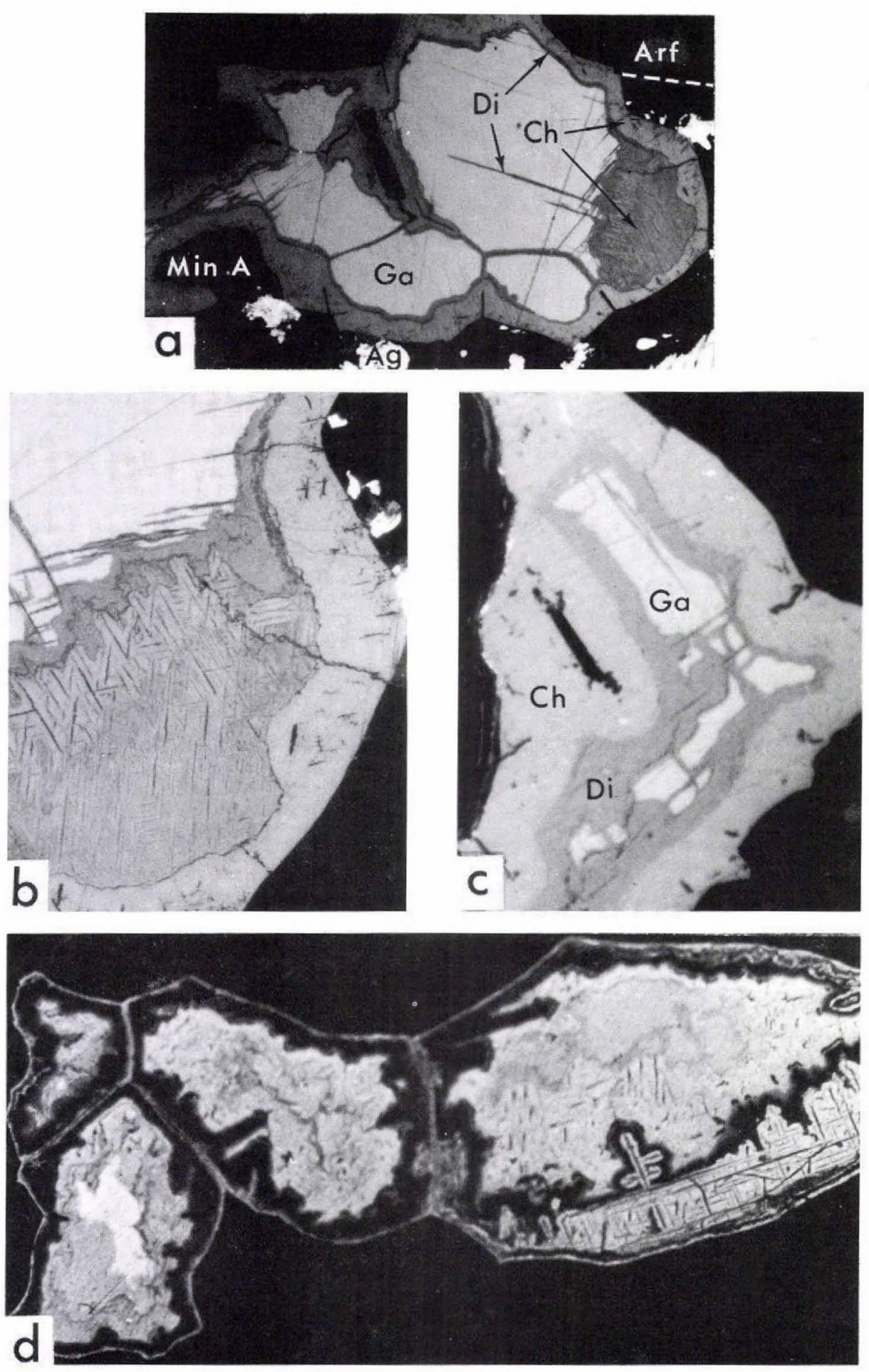




\section{Plate 5}

a. Chalcocite (white) contains crystals of rohaite [white with fractures parallel to (001)] and is partly altered into a very fine-grained mixture of senarmontite and digenite (grey). Black areas are inclusions of aegirine crystals. $(\times 430$. Oil immersion. Sample GGU 151102F).

b. Crystals of rohaite(1) with basal cleavage intergrown with chalcocite(2) lie imbedded in antimonian silver(3). Black areas are silicate grains. (× 310. Oil immersion. Sample GGU 151102.1328).

c. Partly altered rohaite in a matrix of secondary submicroscopically intergrown digenite and senarmontite (dark grey and poorly polished). Fractures in rohaite, parallel to (001) are filled with a secondary unidentified material. A white coloured 'bleached' rim has developed in the rohaite grain against the secondary minerals. $(\times 1130$. Oil immersion. Sample GGU 151102.1331).

d. Two aggregates of very fine-grained senarmontite and digenite have developed during alteration of two rohaite crystals. The boundary in the middle of the photograph between the original rohaite grains is easily recognized. A few silicate grains (black) lie along the boundary. Remnants (white) of one of the rohaite grains occur in the bottom right part of the photograph. An irregular twin pattern is seen in one of the two digenite-senarmontite aggregates (crossed nicols, $\times 310$. Oil immersion. Sample GGU 151102.1331). 

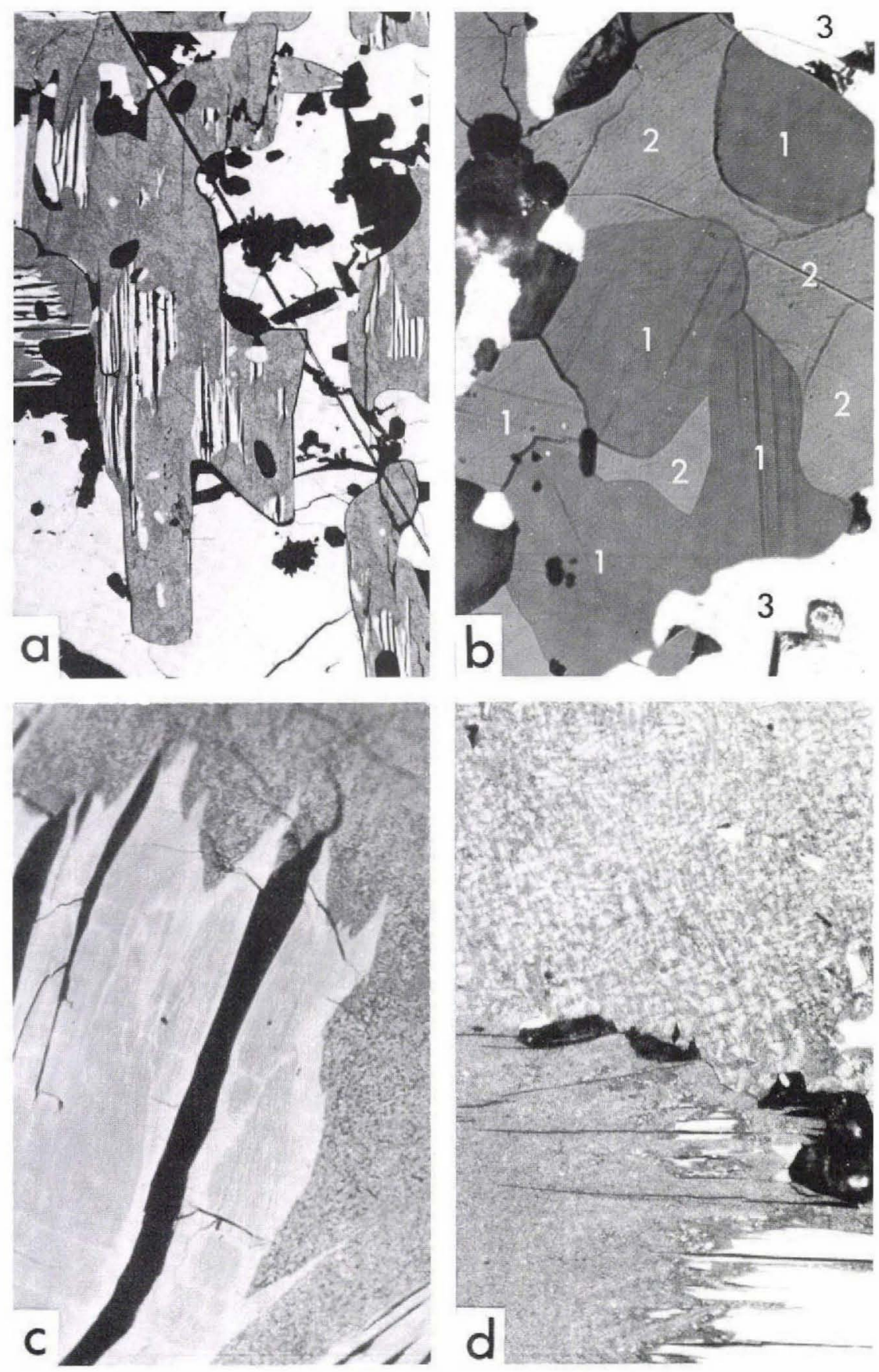


\section{Plate 6}

a. High digenite decomposed into lamellar aggregate of low digenite (medium grey) and chalcocite (light grey). ( $\times$ 780. Oil immersion. Sample GGU 150102c).

b. Lamellar aggregate of low digenite (grey) and chalcocite (light grey and white) is partly replaced by blaubleibender covellite (dark grey) and cut by irregular fractures filled with connellite (black). $(\times 780$. Oil immersion. Sample GGU 150102c).

c. Exsolved lamellae of (?)djurleite in lamellar aggregate of low digenite (medium grey) and chalcocite (light grey). (× 1500. Oil immersion. Sample GGU 150102c).

d. Cuprite (grey) in contact with idiomorphic chalcocite crystals (white). $(\times 450$. Oil immersion. Sample GGU 150102a). 

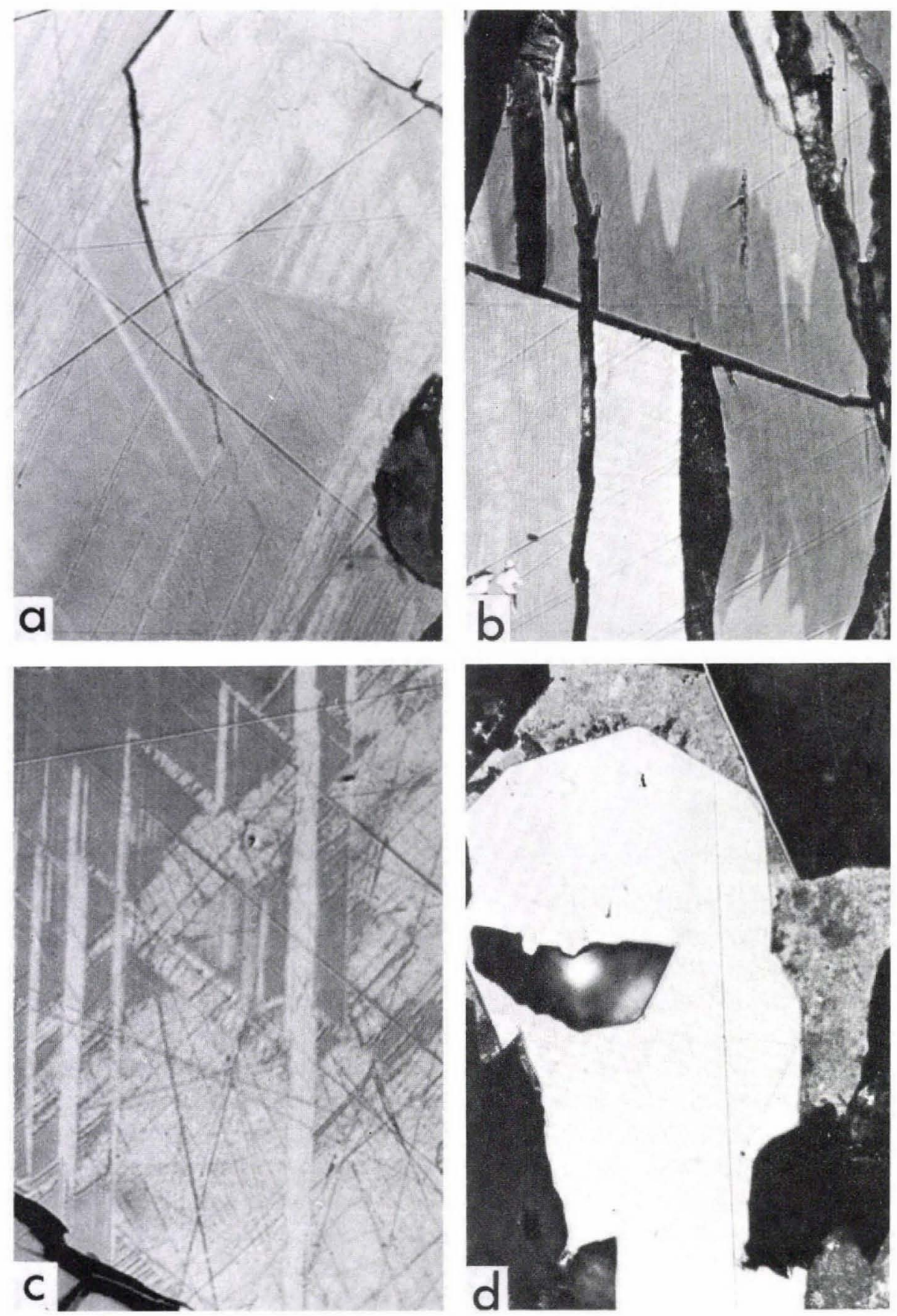


\section{Plate 7}

a. Banded aggregate of Sb-malachite developed by replacement of cuprostibite. A loellingite crystal (arrow) has remained unaffected by the alteration of the cuprostibite, its original host. $(\times 200$. Oil immersion. Sample GGU 151530.6).

b. Aggregate in cuprostibite composed of different cuprite varieties. $(\times 470$. Oil immersion. Sample GGU 151530.151-c).

c. A mixture of various cuprite varieties (Table 9, 1-3) in sharp contact with a veinlet of antimonian silver containing cuprite inclusions (white at bottom) has developed by alteration of cuprostibite (white, centre and top). ( $\times 280$. Oil immersion. Sample GGU 151530.2).

d. Sphaerules of finely banded light and dark 'gel-cuprite' imbedded in considerably darker lead-antimony-silicon-rich 'hydrated cuprite'. The photographed area represents the central portion of a larger aggregate enclosed in cuprostibite and dominated by dark coloured cuprites $(\times 2125$. Oil immersion. Sample GGU 151530.151-c).

e. Portion of cuprostibite aggregate enclosed in silicates (aegirine and analcime) showing partial alteration into very fine-grained senarmontite and associated unidentified mineral. Concentrically arranged cuprite veinlets have developed in the silicate minerals around the partly altered cuprostibite aggregates ( $\times$ 80. Air. Sample GGU 151530.9).

f. Another portion of the same cuprostibite aggregate shown in Plate 7 e. A veinlet of native copper and cuprite extends across the boundary between gangue minerals and cuprostibite partly altered into senarmontite and unidentified mineral. In the gangue minerals only cuprite occurs in the veinlet, and in the cuprostibite area only native copper. The black area in the vein between the native copper and the cuprite is a hole in the polished section ( $\times 350$. Air. Sample GGU 151530.9). 

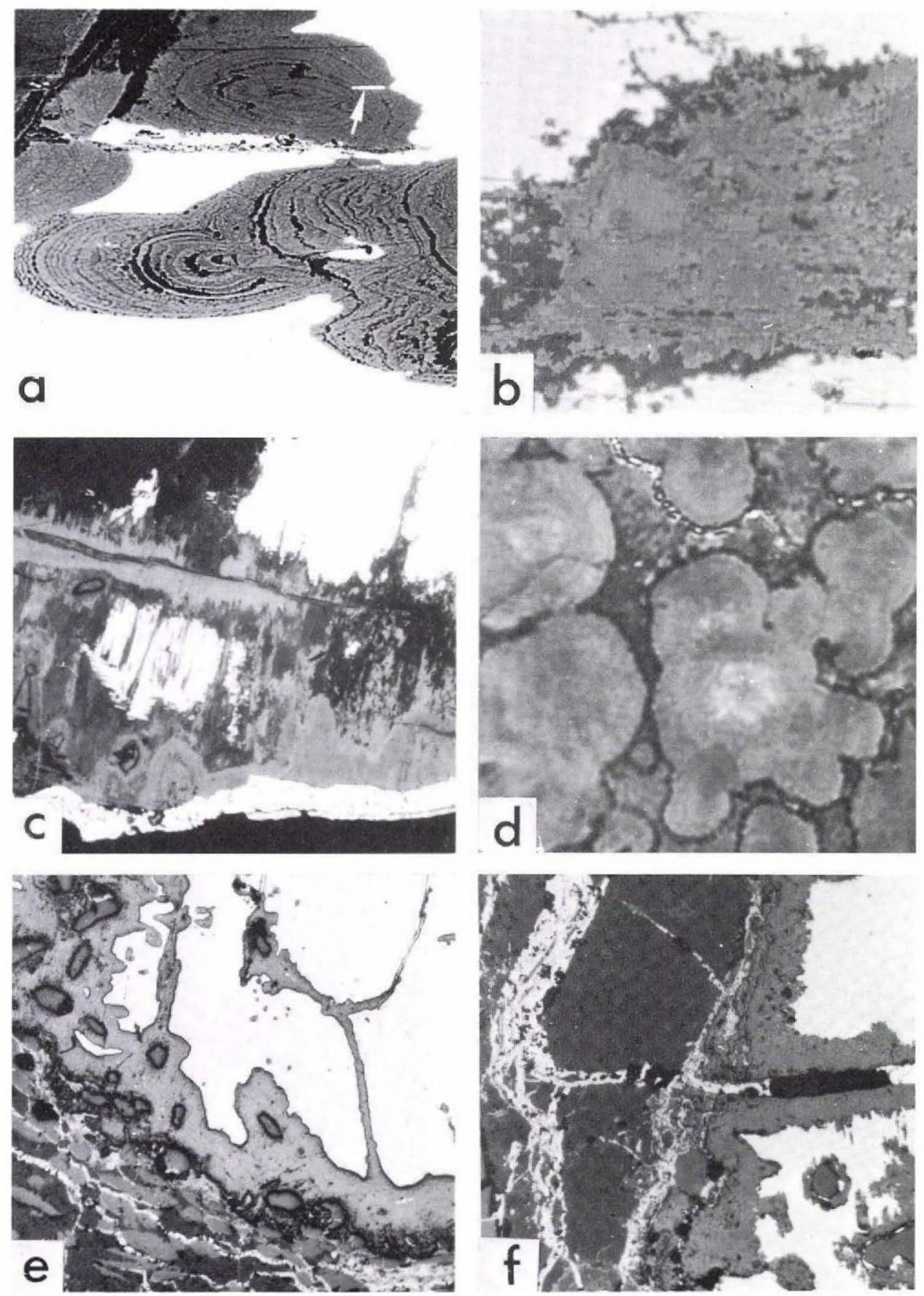


\section{Plate 8}

Electron scanning microphotographs

a. Perfectly shaped connellite crystals. $(\times 1185$. Sample GGU 151337).

b. Stumpy connellite crystals. ( $\times 1185$. Sample GGU 151337$)$.

c. Connellite prism with slightly curved faces. $(\times 7600$. Sample GGU 151337$)$.

d. Slender connellite crystal with slightly curved prism faces as if the crystal was defined by a very steep pyramide. $(\times 1790$. Sample GGU 151337$)$.

e. Octahedra of senarmontite. Note the fine growth lines in the cavity on the large crystal. $(\times 300$. Sample GGU 151395).

f. Aggregate of platy crystals assumed to be either malachite or azurite. $(\times 3150$. Sample GGU 151396). 

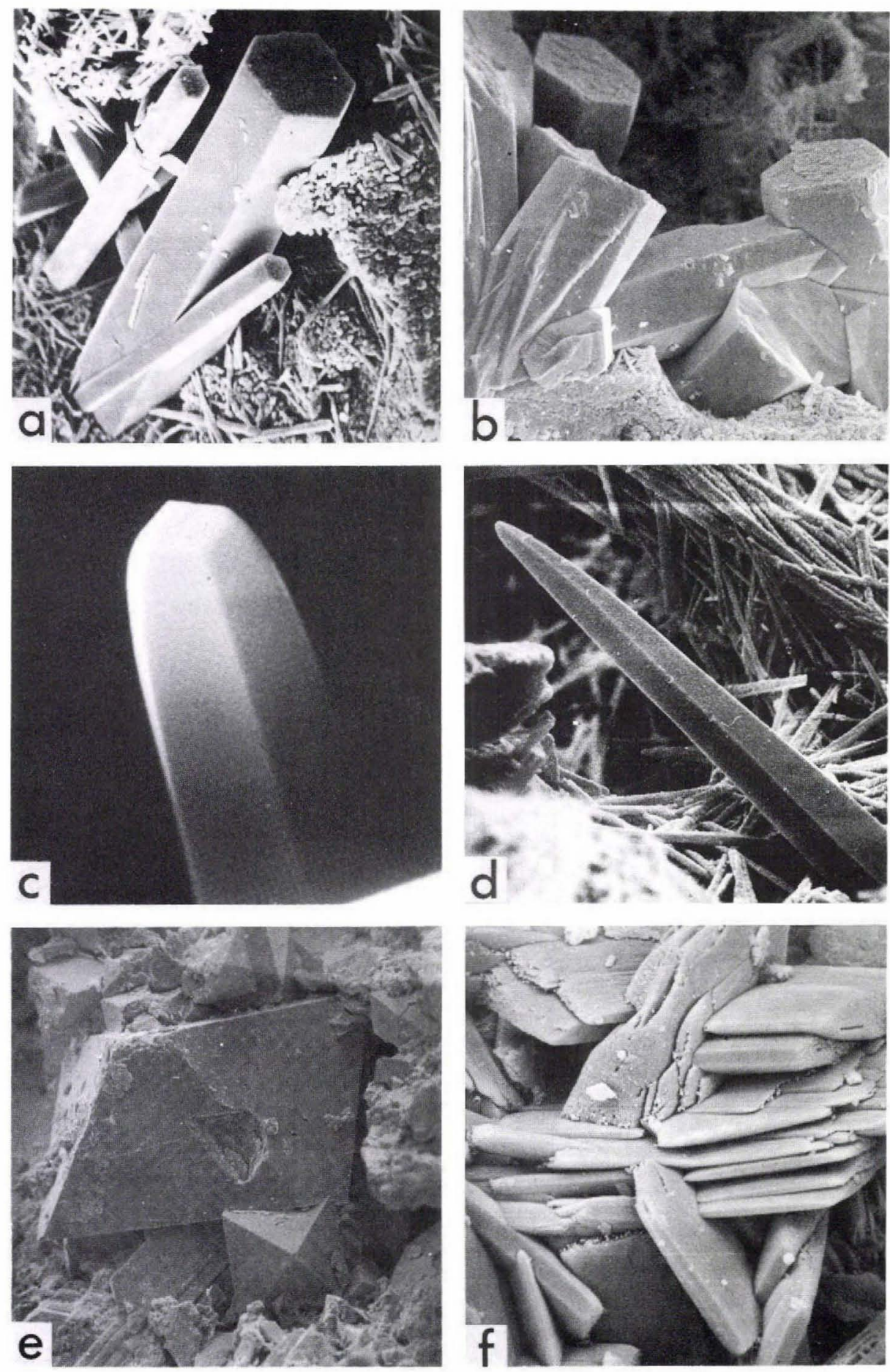
